\title{
Comparative Antigenicity of Thiourea and Adipic Amide Linked Neoglycoconjugates Containing Modified Oligomannose Epitopes for the Carbohydrate-Specific anti-HIV Antibody 2G12
}

\author{
Nino Trattnig, ${ }^{\dagger}$ Patrick Mayrhofer, ${ }^{\ddagger}$ Renate Kunert, ${ }^{\ddagger}$ Lukas Mach, ${ }^{\S}$ Ralph Pantophlet,
} and Paul Kosma*, ${ }^{*}+$ (1)

${ }^{\dagger}$ Department of Chemistry, ${ }^{\ddagger}$ Department of Biotechnology, and ${ }^{\S}$ Department of Applied Genetics and Cell Biology, University of Natural Resources and Life Sciences, Muthgasse 18, A-1190 Vienna, Austria

${ }^{\|}$Faculty of Health Sciences and Department of Molecular Biology and Biochemistry, Simon Fraser University, 8888 University Drive, Burnaby, British Columbia V5A1S6, Canada

\section{Supporting Information}

ABSTRACT: Novel neoglycoproteins containing oligomannosidic penta- and heptasaccharides as structural variants of oligomannose-type $\mathrm{N}$-glycans found on human immunodeficiency virus type 1 gp120 have been prepared using different conjugation methods. Two series of synthetic ligands equipped with 3-aminopropyl spacer moieties and differing in the anomeric configuration of the reducing mannose residue were activated either as isothiocyanates or as adipic acid succinimidoyl esters and coupled to bovine serum albumin. Coupling efficiency for adipic acid connected neoglycoconjugates was better than for the thiourea-linked derivatives; the latter constructs, however, exhibited higher reactivity toward antibody $2 \mathrm{G} 12$, an HIV-neutralizing antibody with exquisite specificity for oligomannose-type glycans. $2 \mathrm{G} 12$ binding avidities for the conjugates, as determined by Bio-Layer Interferometry, were mostly higher for the $\beta$-linked ligands and, as expected, increased with the numbers of covalently linked glycans, leading to approximate $K_{\mathrm{D}}$ values of 10 to $34 \mathrm{nM}$ for optimized ligand-to-BSA ratios. A similar correlation was observed by enzyme-linked immunosorbent assays. In addition, dendrimer-type ligands presenting trimeric oligomannose epitopes were generated by conversion of the amino-spacer group into a terminal azide, followed by triazole formation using "click chemistry". The severe steric bulk of the ligands, however, led to poor efficiency in the coupling step and no increased antibody binding by the resulting neoglycoconjugates, indicating that the low degree of substitution and the spatial orientation of the oligomannose epitopes within these trimeric ligands are not conducive to multivalent $2 \mathrm{G} 12$ binding.

\section{INTRODUCTION}

Glycosidic epitopes present on the gp120 component of the human immunodeficiency virus (HIV) type 1 envelope protein (Env) constitute major targets for broadly neutralizing antibodies (bnAbs). ${ }^{1-4}$ Part of this glycan "canopy" is composed mainly of high-mannose glycans, ranging from $\mathrm{Man}_{5} \mathrm{GlcNAc}_{2}$ to $\mathrm{Man}_{9} \mathrm{GlcNAc}_{2}$, and is referred to also as the "mannose patch". ${ }^{5-7}$ Significant effort has been expended in the production of synthetic glycans and glycopeptides to mimic the high glycan density on the viral surface. ${ }^{8,9}$ Examples include $\mathrm{Man}_{9} \mathrm{GlcNAc}_{2}$ ligands conjugated to the Neisseria meningitidis outer membrane protein complex via a cyclic peptide scaffold, ${ }^{10}$ multivalent attachment of $\mathrm{Man}_{9}$ to the virus-like particle bacteriophage $\mathrm{Q} \beta^{11}$ and dendrimeric oligomannoside ligands linked to bovine serum albumin (BSA), ${ }^{12}$ keyhole limpet hemocyanin $(\mathrm{KLH}),{ }^{13,14}$ or diphtheria toxoid $\left(\mathrm{CRM}_{197}\right){ }^{15}$ In many cases, the copper-assisted cycloaddition reaction between suitable azide and alkyne reactants ("click chemistry") has been used for covalent attachment of the ligands. ${ }^{11,12,14,16-19}$

In those cases where immunization studies have been performed with these synthetic antigens, elicited serum antibodies have shown high affinity for their cognate glycans but weak or no binding to natively glycosylated gp $120 .^{20,21}$ The reason(s) for these outcomes are not clear; one possible factor is B-cell tolerance, due to immune recognition of the presented oligomannosides as "self", ${ }^{22}$ leading to antibody responses capable of binding the synthetic molecules but not natural oligomannose chains. Furthermore, the clustering of oligomannosides on the synthetic antigens may create immunogenic neoepitopes that reduce the likelihood of eliciting antibodies with the proper specificity to HIV.

Received: October 12, 2018

Revised: December 4, 2018

Published: December 7, 2018 


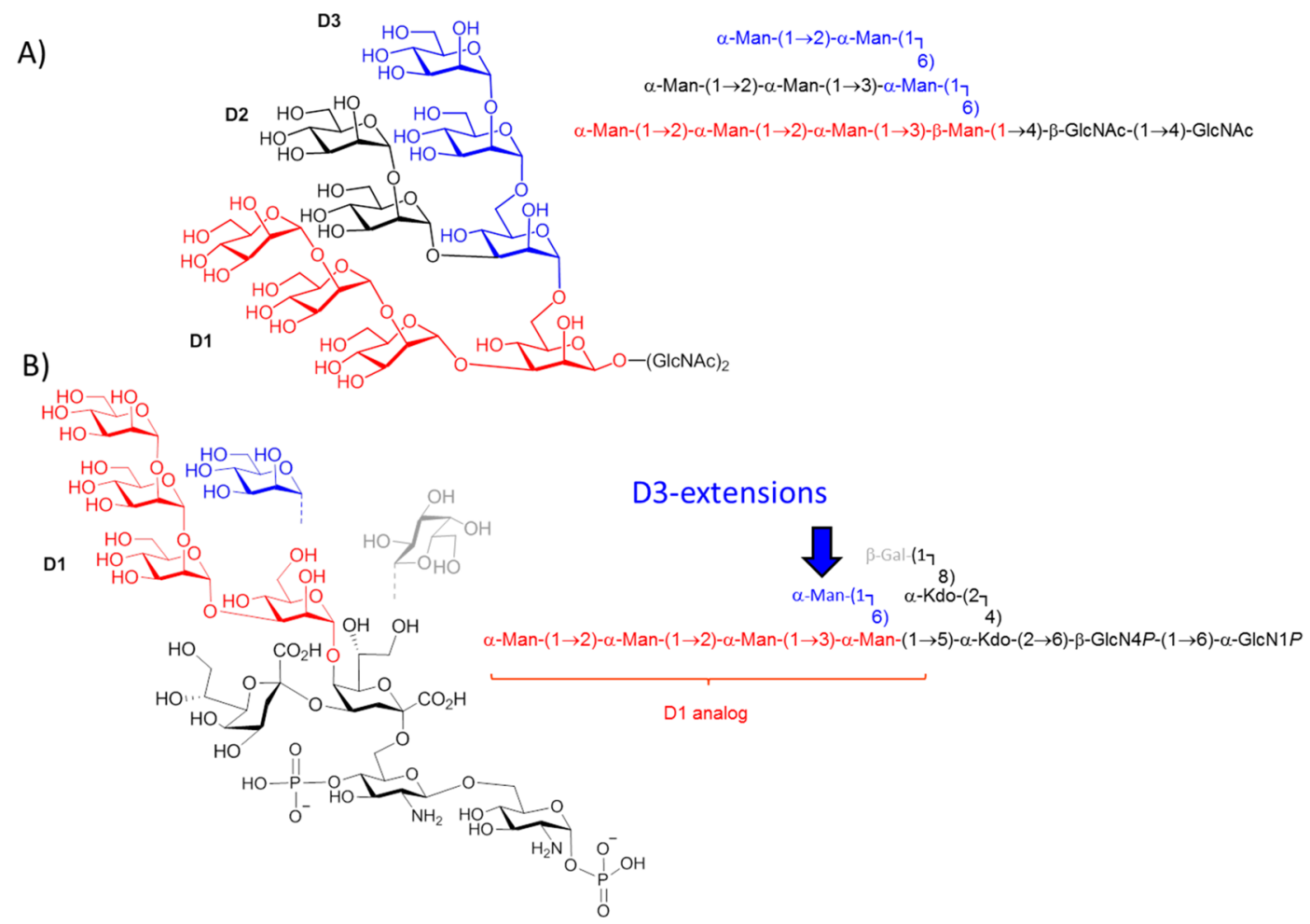

Figure 1. (A) Structure of $\mathrm{Man}_{9} \mathrm{GlcNAc}_{2} \mathrm{~N}$-glycan. (B) Structure of the bacterial lipooligosaccharide isolated from R. radiobacter Rv3. Synthetic extensions are added to the D3-arm (marked in blue). Dashed lines indicate substoichiometric substitution.

Not long ago, a surrogate of oligomannose glycans on HIV was identified in a bacterial lipooligosaccharide (LOS) fragment. The chemical structure of this lipooligosaccharide, isolated from the phytopathogenic Rhizobium radiobacter Rv3 strain, was elucidated and revealed the presence of an $\alpha$-Man- $(1 \rightarrow 2)-\alpha$ Man- $(1 \rightarrow 2)-\alpha$-Man- $(1 \rightarrow 3)$ - $\alpha$-Man oligomannose fragment that resembles the D1 arm of HIV oligomannosides (Figure 1A). ${ }^{23}$ The antigenic similarity to oligomannose was shown by binding to $2 \mathrm{G} 12$, the first antiglycan HIV-1 neutralizing antibody described and the only one described so far to exclusively bind oligomannose, specifically the D1 arm. ${ }^{24-27}$ Notably, immunization of mice with heat-killed bacteria from the Rv3 strain elicited antibodies that were cross-reactive with HIV-1 gp 120. Subsequently, a crystal structure of the bacterial carbohydrate backbone complexed to $2 \mathrm{G} 12$ was determined, providing additional evidence for the structural homology between the bacterial glycan and mammalian oligomannose on the HIV-1 surface. ${ }^{28}$ The obtained crystal structure of the bacterial ligand was then used to model and construct ligands that more closely resemble oligomannose, by including a D3arm surrogate to position 6 of the central mannose unit (Figure 1B).

Recently, we have communicated the chemical synthesis of the bacterial pentasaccharide LOS core comprising the central $\alpha$-Man- $(1 \rightarrow 5)$-linked $\mathrm{Kdo}_{2} \mathrm{GlcNAc}_{2}$ unit $^{29}$ followed by the synthesis of the oligomannosidic mimetics in both anomeric configurations. (Note: the reducing end mannose is $\alpha$-linked in the Rhizobium radiobacter Rv3 lipooligosaccharide in contrast to the $\beta$-linkage in $\mathrm{N}$-glycoproteins. ${ }^{30}$ ) A small library of 2 pentamannosides and 4 heptamannosides has been prepared as spacer-equipped ligands as well as their respective BSA conjugates. The envisaged increased antigenicity of the modified D3-arm was verified in the crystal structure of a heptamannoside ligand bound to PGT128, one of several glycan-specific antibodies described more recently with broad HIV-neutralizing activity. ${ }^{31}$ Moreover, a BSA neoglycoconjugate containing the heptasaccharide $\alpha$-Man- $(1 \rightarrow 2)-\alpha$-Man- $(1 \rightarrow 2)-\alpha$-Man- $(1 \rightarrow$ $3)$ - $[\alpha$-Man- $(1 \rightarrow 2)-\alpha$-Man- $(1 \rightarrow 6)-\alpha$-Man- $(1 \rightarrow 6)]-\beta$-Man as ligand induced modest neutralizing antibody responses in human-antibody transgenic rats. ${ }^{30}$

Parallel to our studies to design glycoconjugates that can elicit antibodies of similar specificity and neutralizing activity to PGT128 and related antibodies, we have also set out to assess the impact of these modified bacterial oligomannoside mimetics toward recognition by $2 \mathrm{G} 12$. Herein we present the synthesis and 2 G12 binding properties of additional neoglycoconjugates, including a clustered multivalent presentation of these oligomannoside epitopes. Specifically, we evaluate the influence of two different spacer groups and conjugation methods with respect to coupling efficiency and antibody binding properties.

\section{RESULTS AND DISCUSSION}

Synthesis of Thiourea and Adipic Amide Linked Neoglycoconjugates. The previously described ${ }^{30}$ anomeric oligomannosides $1,3,5,7,9$, and 11, equipped with a 3aminopropyl spacer group, were directly activated for coupling to BSA. Alternatively they were converted in good to excellent yields into the corresponding 3 -azidopropyl derivatives $2,4,6,8$, 10, and 12 (Schemes 1 and 2$)^{32}$ to enable "click chemistry" via 1,3-dipolar cycloaddition reactions. ${ }^{33,34}$

The azidopropyl spacer derivatives were purified using gel chromatography on LH-20 resin and fully characterized by NMR and HRMS. Notably, the NMR data of the 3-amino- and 3-azidopropyl group, respectively, in compounds 1-12 indicated a restricted motional freedom for the $\alpha$-anomeric ligands, as seen from signal splitting of the geminal $\mathrm{N}$-linked methylene protons at $\sim 3.40 \mathrm{ppm}$ and $\mathrm{C}$-linked $\mathrm{CH}_{2}$ signals in the aliphatic region. The $\beta$-anomers, in contrast, consistently 
Scheme 1. Synthesis of Anomeric Mannopentaoside Azidopropyl Spacer Derivatives 2 and $4^{a}$

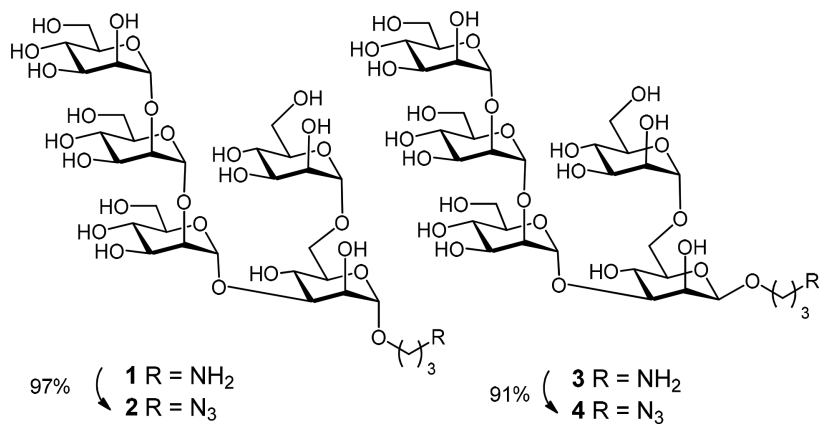

${ }^{a}$ Reagents and conditions: $\mathrm{K}_{2} \mathrm{CO}_{3}$, imidazole-1-sulfonyl azide. $\mathrm{HCl}$, $0.1 \mathrm{M} \mathrm{CuSO}_{4} \cdot 5 \mathrm{H}_{2} \mathrm{O}, 2: 1 \mathrm{MeOH}-\mathrm{H}_{2} \mathrm{O}$, rt $24 \mathrm{~h}$.

showed magnetic equivalence of these protons, indicative of greater motional freedom.

In previous reports, we reacted the terminal amino groupcontaining oligomannose ligands with thiophosgene and then coupled the resulting isothiocyanates to BSA to yield thiourealinked neoglycoconjugates (Scheme 3). ${ }^{21,30}$ To achieve a sufficient ligand density, a high molar excess of the spacer glycoside in the coupling reaction was needed, resulting in ligand to BSA ratios of up to $6.4: 1$, as measured by MALDI-TOF mass spectrometry. ${ }^{30}$ The low coupling efficiency of the isothiocyanate conjugation experiments can be explained by a lower concentration of the protein used and the competing, reversible reaction of the activated ligand with sulfhydryl groups leading to unstable dithiocarbamate derivatives. ${ }^{35}$

As an alternative conjugation method, the 3-aminopropyl spacer derivatives were extended by an adipate linker followed by conversion into BSA conjugates. First, the lead heptasaccharides $\mathbf{5}$ and $\mathbf{7}$ were subjected to a two-step procedure starting with disuccinimido adipate (DSAP) reagent 19 to give the activated intermediate monoester derivative followed by reaction with BSA to furnish the adipic bisamide linked neoglycoconjugates $\mathbf{2 0}$ and $\mathbf{2 1}$, respectively (Scheme 4). ${ }^{36}$ Conjugation using the adipic amide protocol led to a significantly improved coupling efficiency (Table 1). The coupling efficiency decreased slightly when we attempted to prepare conjugates containing $\geq 8$ oligomannoside moieties, most likely because the most reactive amino groups of the protein had already been substituted (entries 10 and 13). In a previous study, three lysine residues (Lys 235, Lys 437, and Lys 455) had been identified as the most reactive and sterically accessible sites in squaric-acid based synthesis of BSA neoglycoconjugates. ${ }^{37,38}$ In general, reactivity of the $\beta$-linked heptamannoside 7 was slightly better than for its $\alpha$-anomeric counterpart 5 (entries 1 and 6; 9 and 12), which is consistent with the NMR finding that the $\alpha$-spacer group had a reduced conformational flexibility (vide supra).

2G12 Binding to Neoglycoconjugates. Apparent binding affinities of the anti-HIV antibody 2 G12 for the constructed BSA conjugates, ranging in ligand density from 1.5 to 8.3 ligands per BSA molecule, were determined by Biolayer Interferometry (BLI). In a first series of experiments performed with select thiourea-linked glycoconjugates, 14, 16c, and 17 were identified as being bound most strongly by $2 \mathrm{G} 12$, with approximate $K_{\mathrm{D}}$ values ranging from 19 to $34 \mathrm{nM}$ (Figure 2). Substantially lower binding was observed for the $\alpha$-anomeric pentasaccharide conjugate $13(183 \mathrm{nM})$ and in particular for the $\beta$-anomeric heptasaccharide antigen $18(394 \mathrm{nM})$, harboring the artificial $\alpha$ $(1 \rightarrow 4)$-linkage for the D3 arm-like extension. These differences are not explained by differences in coupling density as conjugates 14 and 17, both of which are bound well by 2 G12, carry an average number of 3.3 and 3.4 glycans per BSA, respectively, that matches that of the poorly bound conjugates 13 and 18, which contain on average 3.5 and 3.1 glycans per $\mathrm{BSA}$, respectively. Of the $\beta$-linked thiourea glycoconjugates assayed in this first set of experiments, compound $16 \mathrm{c}$ was bound most strongly, with an apparent $K_{\mathrm{D}}$ of $23 \mathrm{nM}$, which, however, is about an order of magnitude higher than the reported $^{39} K_{\mathrm{D}}(2.5 \mathrm{nM})$ for the interaction between $2 \mathrm{G} 12$ and HIV-1 gp140. With the exception of conjugate 13, the dissociation rates determined in the BLI experiments displayed a similar trend as the $K_{\mathrm{D}}$ values.

To assess the optimum ligand density for $2 \mathrm{G} 12$ binding, thiourea- and adipic acid-linked neoglycoconjugates of select substitution degrees containing the D3-arm extended heptasaccharide unit in both anomeric forms were then evaluated. No binding was observed for conjugates containing fewer than two ligands per BSA molecule (16a, 20a; data not shown), which is consistent with the need for $2 \mathrm{G} 12$ to bind bivalently to achieve avid interaction with antigen. ${ }^{25,27}$ Conjugates $\mathbf{1 6 b}$ and $\mathbf{2 0 b}$ bound to $2 \mathrm{G} 12$ with low affinity $\left(K_{\mathrm{D}}>1 \mu \mathrm{M}\right)$, precluding accurate determination of $K_{\mathrm{D}}$ and $k_{\text {off }}$ (data not shown). At comparable ligand densities, the thiourea constructs were superior binders relative to the adipic acid conjugates. The better binding of the thiourea derivatives is also discernible when comparing the apparent $K_{\mathrm{D}}$ values (Table 2). To achieve a similar apparent avidity, adipic acid conjugates required a higher ligand/BSA ratio (compare conjugate $15 \mathrm{c}$ and $20 \mathrm{c}$, as well as

Scheme 2. Synthesis of Anomeric Mannoheptaoside Azidopropyl Spacer Derivatives 6, 8, 10, and $12^{a}$

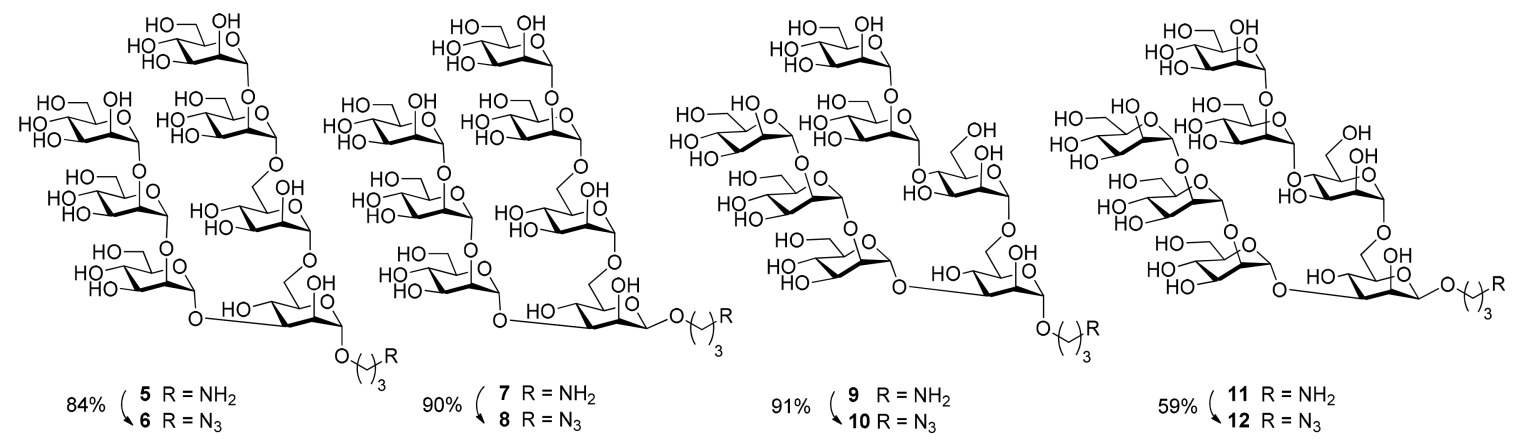

${ }^{a}$ Reagents and conditions: $\mathrm{K}_{2} \mathrm{CO}_{3}$, imidazole-1-sulfonyl azide $\cdot \mathrm{HCl}, 0.1 \mathrm{M} \mathrm{CuSO}_{4} \cdot 5 \mathrm{H}_{2} \mathrm{O}, 2: 1 \mathrm{MeOH}-\mathrm{H}_{2} \mathrm{O}, \mathrm{rt}, 24 \mathrm{~h}$. 
Scheme 3. Synthesis of Thiourea-Linked Neoglycoconjugates $13-18^{30}$

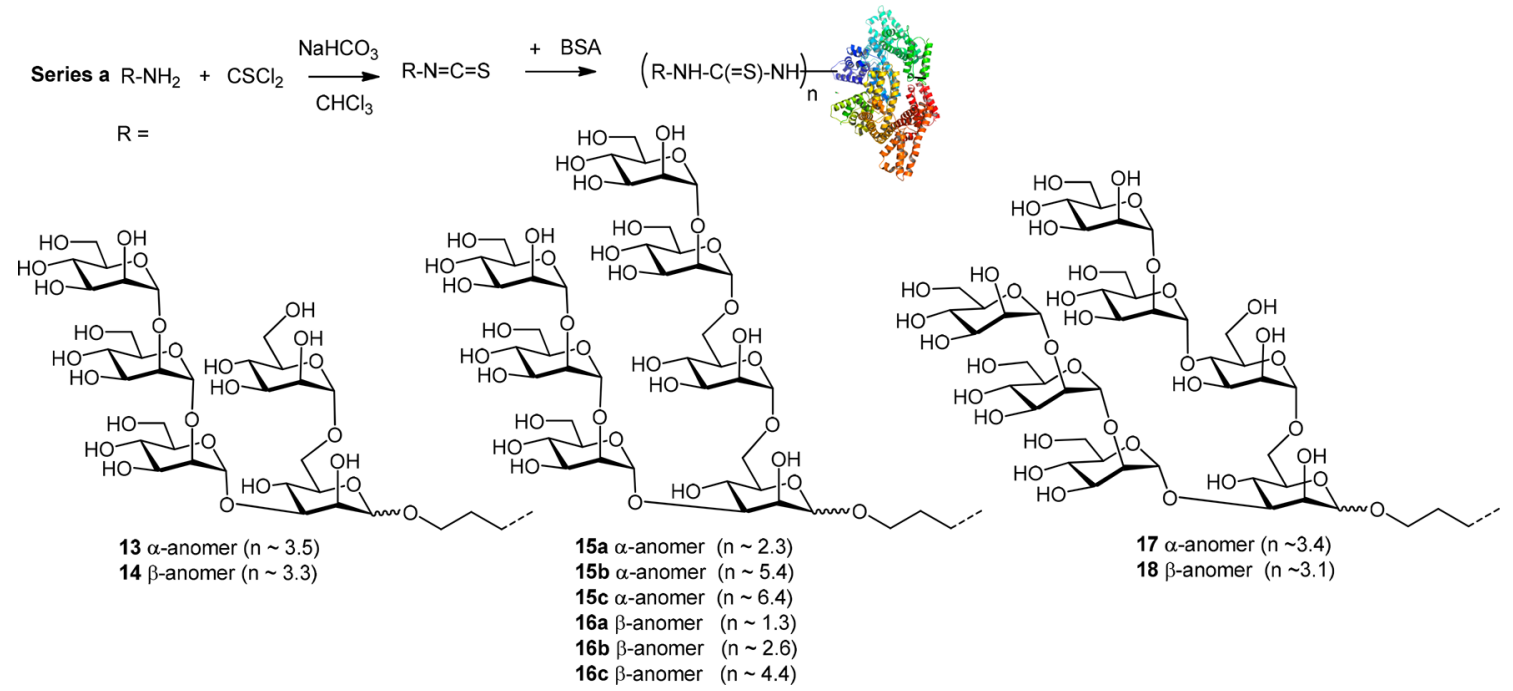

Scheme 4. Synthesis of Adipic Amide-Linked Neoglycoconjugates 20 and 21

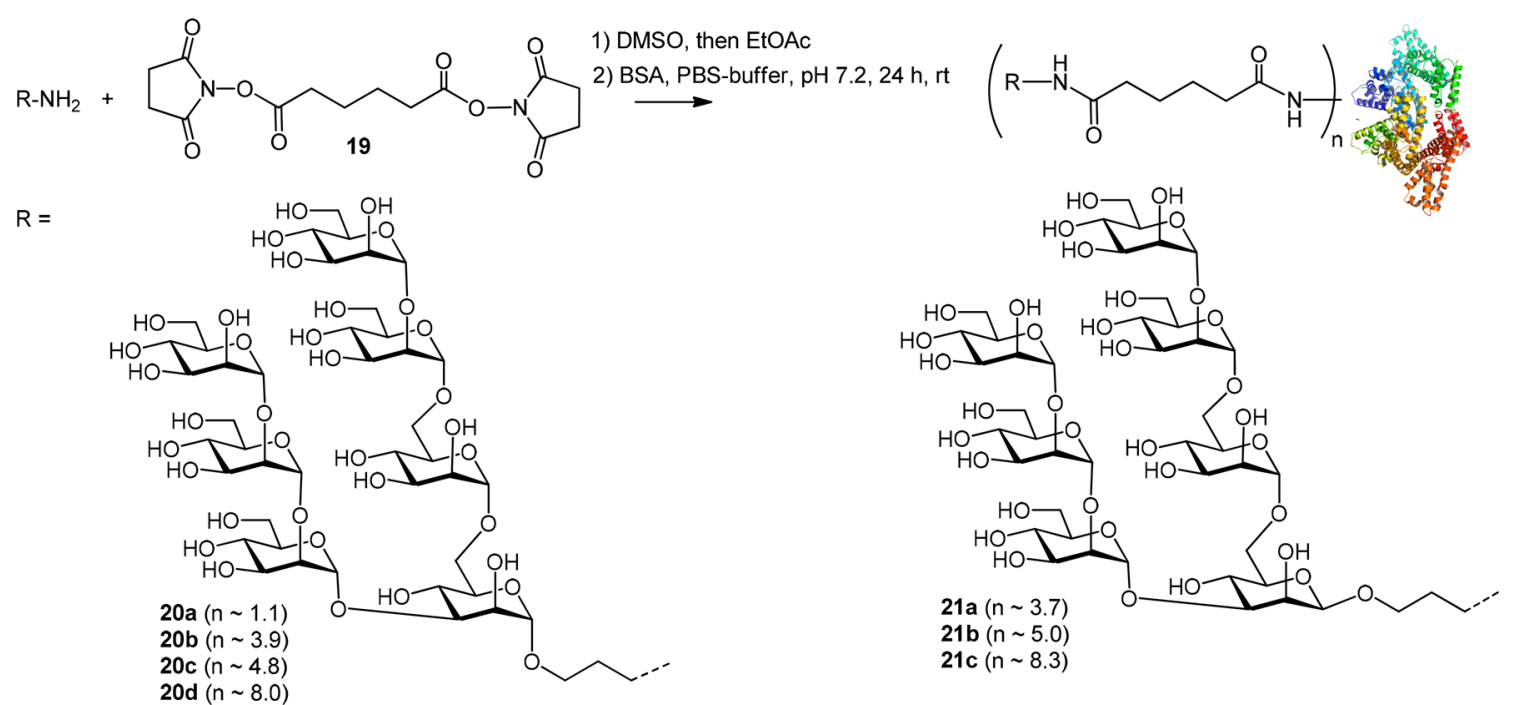

Table 1. Coupling Efficiency of Anomeric Heptamannoside Spacer Derivatives 5 and 7 to BSA

\begin{tabular}{|ccccccc|}
\hline Entry & $\begin{array}{c}\text { Spacer } \\
\text { glycoside }\end{array}$ & $\begin{array}{c}\text { Protein } \\
\text { concentration } \\
(\mathrm{nM})\end{array}$ & Molar ratio ${ }^{\mathrm{a}}$ & Conjugate & $\begin{array}{c}\text { Ligand/BSA } \\
\text { ratio }\end{array}$ & Efficiency [\%] $^{\text {b }}$ \\
\hline 1 & $\mathbf{5}$ & 8 & 74 & $\mathbf{1 5 a}$ & 2.3 & 3.1 \\
2 & $\mathbf{5}$ & 10 & 190 & $\mathbf{1 5 b}$ & 5.4 & 2.8 \\
3 & $\mathbf{5}$ & 6 & 330 & $\mathbf{1 5 c}$ & 6.4 & 1.9 \\
4 & $\mathbf{7}$ & 10 & 27 & $\mathbf{1 6 a}$ & 1.3 & 5.6 \\
5 & $\mathbf{7}$ & 10 & 55 & $\mathbf{1 6 b}$ & 2.6 & 4.7 \\
6 & $\mathbf{7}$ & 10 & 74 & $\mathbf{1 6 c}$ & 4.4 & 5.9 \\
7 & 5 & 33 & 5 & $\mathbf{2 0 a}$ & 1.1 & 22.0 \\
8 & 5 & 50 & 10 & $\mathbf{2 0 b}$ & 3.9 & 39.0 \\
9 & 5 & 41 & 20 & $\mathbf{2 0 c}$ & 4.8 & 24.0 \\
10 & 5 & 17 & 50 & $\mathbf{2 0 d}$ & 8.0 & 16.0 \\
11 & 7 & 20 & 20 & $\mathbf{2 1 a}$ & 3.7 & 18.5 \\
12 & 7 & 40 & 20 & $\mathbf{2 1 b}$ & 5.0 & 25.0 \\
13 & 7 & 45 & 40 & $\mathbf{2 1 c}$ & 8.3 & 20.8 \\
\hline
\end{tabular}

${ }^{c}$ Thiourea-based glycoconjugates are marked in blue; adipic acid connected conjugates in red. ${ }^{\mathrm{a}}$ Molar ratio of aminopropyl glycoside to BSA used in the conjugation reaction. ${ }^{b}$ Efficiency defined as the percentage of reacted glycoside. 

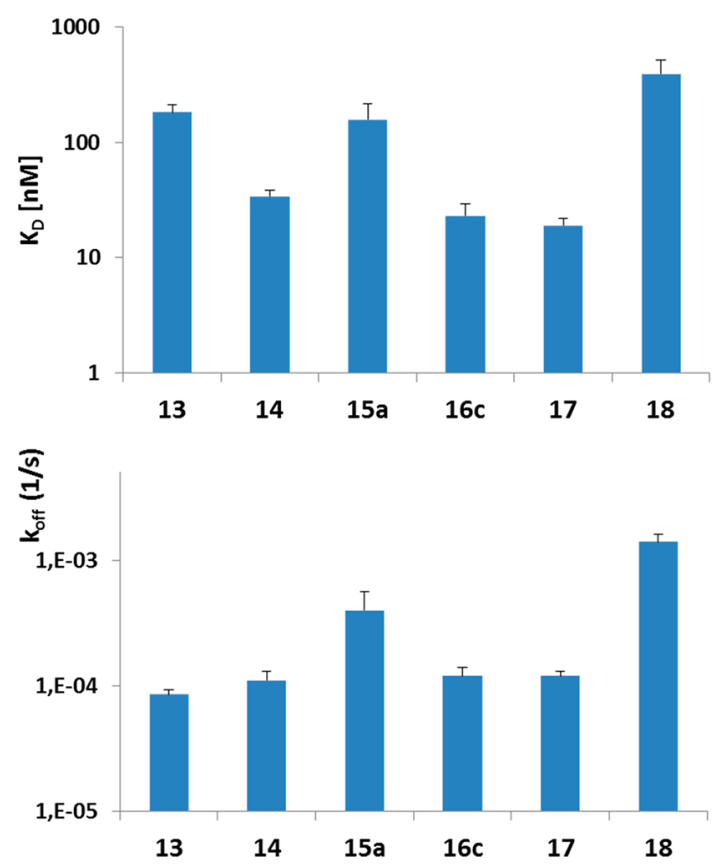

Figure 2. Apparent binding avidities determined by BLI for select thiourea-linked glycoconjugates to $2 \mathrm{G} 12 . K_{\mathrm{D}}, k_{\mathrm{off}}$ and SEM (error bars) are based on 3-4 independent experiments, performed at glycoconjugate concentrations ranging from $16 \mu \mathrm{g} / \mathrm{mL}$ to $1 \mathrm{mg} / \mathrm{mL}$ (corresponding to a concentration range of 0.2 to $14 \mu \mathrm{M}$ ). Only measurements with a good curve fit $\left(R^{2}>0.85\right)$ were used for $K_{\mathrm{D}}$ and $k_{\text {off }}$ determination.

$16 \mathrm{c}$ and $\mathbf{2 1 b}$, respectively). Furthermore, and similar to the coupling efficiency (Table 1), conjugates with the branching mannose in the $\beta$-anomeric configuration displayed a tendency to be bound more strongly by $2 \mathrm{G} 12$ than their $\alpha$-anomeric counterparts.

In summary, the optimum ligand density was found to be in a range of 4-6 ligands per BSA molecule for the thiourea adducts, whereas the adipic acid linked conjugates required a higher copy number to attain comparable binding avidities for $2 \mathrm{G} 12$.

Comparison of the Antigenic Properties of Synthetic Oligomannose Glycosides to Natural Oligomannose Using 2G12 and the 2G12 I19R Mutant. A mutant version of $2 \mathrm{G} 12$ was used to compare the antigenic properties of selected synthetic oligomannose glycosides with those of HIV glycans. 2G12 exists naturally as a domain-exchanged antibody, resulting in two conventional antibody-combining sites and a homodimeric $V_{\mathrm{H}} / V_{\mathrm{H}}$ ' interface formed by crossover of the antibody heavy chains. The multivalent binding surface thus created accounts for the high selectivity of $2 \mathrm{G} 12$ for clustered oligomannose chains such as presented on the HIV envelope glycoprotein surface. ${ }^{25}$ Others have shown that mutating Ile19 (Kabat numbering) in the 2G12 heavy chain to Arg yields a nondomain exchanged version with an archetypical Y-shaped architecture. ${ }^{40}$ The I19R mutant (2G12-I19R) binds oligomannose chains in the same manner as wild-type $2 \mathrm{G} 12$, but does so substantially less avidly and is unable to neutralize HIV. To evaluate the antigenic presentation of oligomannosides on select neoglycoconjugates described above, wild-type 2G12 and mutant 2G12-I19R were assessed by ELISA for binding to the adipic acid linked glycoconjugates compared to recombinant HIV gp140. Substantial binding of 2G12-I19R to gp140 and the glycoconjugates was only observed when the avidity of the antibody was increased by first precomplexing it with an anti-Fc antibody, as observed also by others. ${ }^{40}$ Both antibodies bound most strongly to the $\beta$-linked neoglycoconjugate $21 \mathrm{c}$; slightly lower binding was observed for the equivalent $\alpha$-linked anomer neoglycoconjugate 20d at comparable ligand density (Figure 3). However, and noticeably, similar to the results obtained in BLI experiments, binding of wild-type $2 \mathrm{G} 12$ to the neoglycoconjugates was significantly lower than to gp140, illustrating that even at higher ligand density, the neoglycoconjugates do not entirely mimic the organization of natural oligomannose on the HIV envelope glycoprotein. In contrast, binding of 2G12-I19R to neoglycoconjugates $20 \mathrm{~b}$ and $2 \mathbf{b}$ was stronger than to gp 140 (Figure 3), indicating that these glycoconjugates could represent unique vaccine candidates for priming the elicitation of $2 \mathrm{G} 12$ like antibody responses.

Synthesis of Neoglycoconjugates Containing Clustered/Dendrimeric Oligomannose Epitopes. In the past, multivalent presentation of oligomannoside ligands for the interaction with the extended paratope of $2 \mathrm{G} 12$ has frequently been based on pentyl, 3-oxapentyl, or hexyl groups terminated by azido or amino groups. ${ }^{11,21,26,14,15}$ The inherent flexibility of such long-chain spacer groups, however, increases the entropic

Table 2. BLI Data for Binding of Thiourea and Adipic Acid Conjugates to 2G12

\begin{tabular}{|c|c|c|c|c|c|c|}
\hline Conjugate & Concentration range $(\mu \mathrm{M})$ & Measurements $^{a}$ & Experiments & $k_{\mathrm{on}} \pm \operatorname{SEM}^{b}\left(\mathrm{M}^{-1} \mathrm{~s}^{-1}\right)$ & $k_{\mathrm{off}} \pm \operatorname{SEM}^{b}\left(\mathrm{~s}^{-1}\right)$ & $K_{\mathrm{D}} \pm \mathrm{SEM}^{b}(\mathrm{nM})$ \\
\hline 13 & $0.23-14.4$ & 18 & 4 & $5.1 \pm 0.3 \times 10^{2}$ & $8.5 \pm 0.8 \times 10^{-5}$ & $183 \pm 30$ \\
\hline 14 & $0.45-7.2$ & 15 & 3 & $3.8 \pm 0.5 \times 10^{3}$ & $1.1 \pm 0.2 \times 10^{-4}$ & $34 \pm 4$ \\
\hline $15 \mathrm{a}$ & $0.23-14.4$ & 23 & 4 & $4.5 \pm 1.0 \times 10^{3}$ & $4.0 \pm 1.6 \times 10^{-4}$ & $157 \pm 61$ \\
\hline $15 \mathrm{c}$ & $0.84-6.7$ & 12 & 3 & $3.2 \pm 0.1 \times 10^{4}$ & $5.8 \pm 0.8 \times 10^{-4}$ & $19 \pm 3$ \\
\hline $16 c$ & $0.22-13.9$ & 26 & 4 & $1.1 \pm 0.1 \times 10^{4}$ & $1.2 \pm 0.2 \times 10^{-4}$ & $23 \pm 6$ \\
\hline 17 & $0.22-14.2$ & 26 & 4 & $1.0 \pm 0.1 \times 10^{4}$ & $1.2 \pm 0.1 \times 10^{-4}$ & $19 \pm 3$ \\
\hline 18 & $0.45-7.1$ & 16 & 4 & $4.5 \pm 0.7 \times 10^{3}$ & $1.4 \pm 0.2 \times 10^{-3}$ & $394 \pm 125$ \\
\hline $20 c$ & $0.84-6.8$ & 12 & 3 & $2.6 \pm 0.2 \times 10^{4}$ & $1.4 \pm 0.1 \times 10^{-3}$ & $71 \pm 2$ \\
\hline $20 d$ & $0.81-6.5$ & 12 & 3 & $1.5 \pm 0.1 \times 10^{4}$ & $2.1 \pm 0.4 \times 10^{-3}$ & $319 \pm 112$ \\
\hline $21 b$ & $0.85-6.8$ & 9 & 3 & $1.3 \pm 0.1 \times 10^{4}$ & $7.4 \pm 1.1 \times 10^{-4}$ & $76 \pm 17$ \\
\hline $21 \mathrm{c}$ & $0.81-6.5$ & 5 & 2 & $3.2 \pm 0.1 \times 10^{4}$ & $2.9 \pm 0.1 \times 10^{-4}$ & $10 \pm 1$ \\
\hline 32 & $0.45-7.2$ & 10 & 3 & $1.5 \pm 0.1 \times 10^{4}$ & $6.1 \pm 0.3 \times 10^{-4}$ & $46 \pm 4$ \\
\hline 33 & $0.46-7.3$ & 2 & 2 & $7.3 \pm 6.8 \times 10^{3}$ & $2.0 \pm 1.1 \times 10^{-3}$ & $274^{c}$ \\
\hline 34 & $0.43-6.8$ & 3 & 2 & $7.6 \pm 4.3 \times 10^{4}$ & $1.6 \pm 0.6 \times 10^{-3}$ & $23 \pm 4$ \\
\hline 35 & $0.45-7.2$ & 2 & 2 & $1.9 \pm 0.4 \times 10^{4}$ & $2.3 \pm 1.3 \times 10^{-3}$ & $121^{c}$ \\
\hline
\end{tabular}

${ }^{a}$ Only measurements with $R^{2} \geq 0.85$ were included. ${ }^{b} \mathrm{SEM}$, standard error of the mean. ${ }^{c}$ Calculated as $k_{\text {off }} / k_{\text {on }}$. 

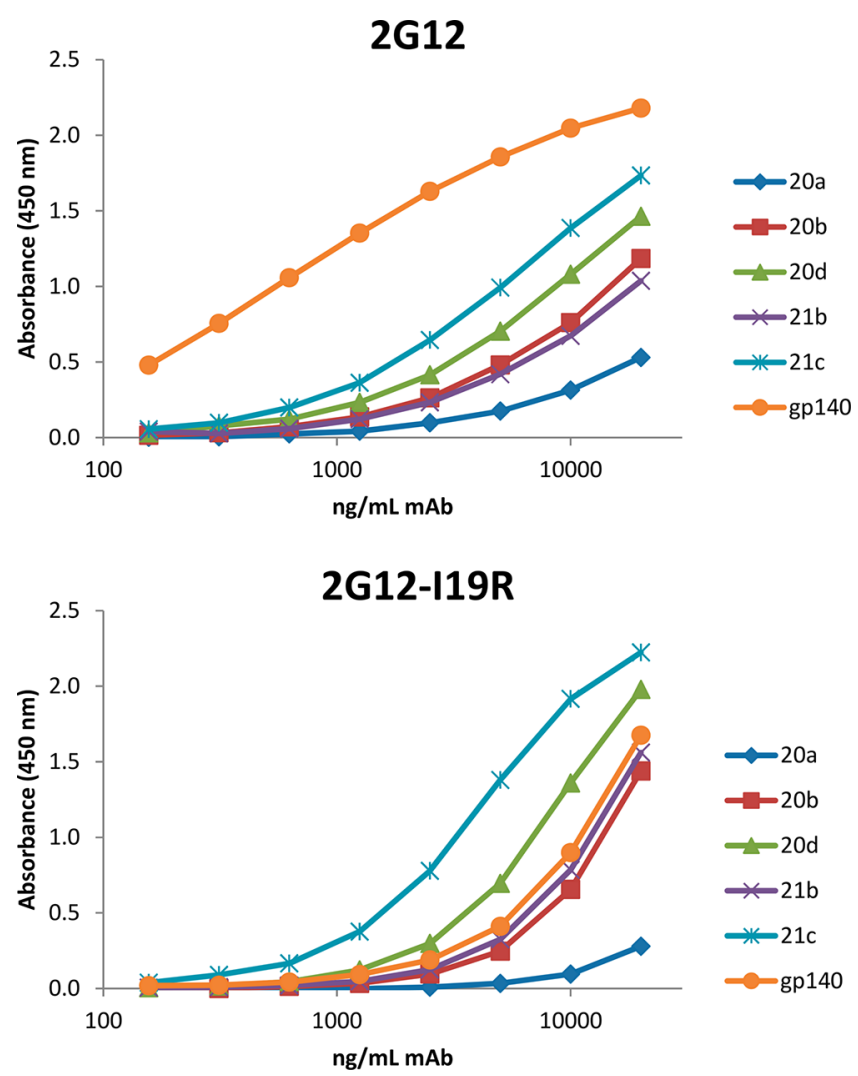

Figure 3. Binding of adipic acid linked neoglycoconjugates 20a, 20b, 20d, 21b, and 21c to wild-type 2G12 (top) and to the 2G12-I19R mutant (bottom) as determined by ELISA. Plates were coated with equal amounts of gp140 and neoglycoconjugates. This experiment has been performed twice with similar results.

penalty in the binding process. In contrast, rigidification of ligands may contribute to free energy gains in the binding process to proteins. ${ }^{41-43} \mathrm{We}$ thus set out to assess the impact of the short three-carbon aglycon directly tethered to a triazole scaffold, which should significantly confine the conformational space of the oligomannose fragments.

To this end, the known tris-propyne substituted amine $23^{44,45}$ was used as reagent for the cycloaddition reaction. ${ }^{46}$ As alternate chain-elongated scaffold the di-5-aminopentanoic amide derivative 24 was also synthesized. Thus, the Boc-protecting group from 22 was cleaved by treatment with TFA to give 23, followed by HATU-promoted elongation of the liberated amino group with a second Boc-protected 5-amino pentanoic acid residue to furnish 24 in $67 \%$ yield (Scheme 5).

The ensuing click reactions with the azide-terminated derivatives 2 and 4 were performed in moderate yields of 35$46 \%$ only, most likely due to the steric congestion present in the dense arrangement of the triazole-tethered oligomannosides (Scheme 6). The oligomannoside ligands were used in 3.3-3.6- fold excess to enforce the complete formation of three triazole rings. However, incompletely substituted reaction products remained in the reaction mixture. Separation of the 3-foldsubstituted products from under-derivatized species and unreacted starting material could be achieved by size exclusion chromatography on Sephadex LH-20. The degree of substitution was determined from the ${ }^{1} \mathrm{H}$ NMR signal intensity of the Boc group relative to the triazole protons, which agreed fully with the mass data obtained by MALDI-TOF measurements. The high steric hindrance of the ligands had a detrimental effect on the conjugation experiments, which were performed with the $\alpha$-anomeric pentamannoside $\mathbf{2}$ as model compound. First, compound 2 was subjected to the click reaction with the shortchain linker 22 in a moderate $46 \%$ yield. The resulting triazole derivative 25 was then treated with TFA-to expose the terminal amino group-giving 26 in $97 \%$ yield. Activation of pentasaccharide ligand 26 with squaric acid ${ }^{47-49}$ under nonoptimized conditions mainly resulted in recovery of unreacted protein and a small fraction of substituted product with a very low ligand density (0.1 ligand/BSA, data not shown). Use of the chain extended version 29, derived from the Bocprotected precursor 27 upon acid treatment, led to somewhat better results and provided squaric acid conjugate $\mathbf{3 1}$ with a ligand copy number of 0.5 per BSA. Due to the improved incorporation of the ligand when using the extended aminopentanoic amide linker, thiourea conjugates were similarly prepared from the derivatives 29 and 30 , which gave conjugates 32 with a copy number of 0.8 , and 33 with 0.5 ligand/BSA ratio, respectively. Similar to the results obtained with the monovalent ligands (Table 1), the adipic amide conjugation method performed better, providing conjugates 34 and 35 with ligand/protein ratios of 3:1 and 1.3:1, respectively (Table 3).

As measured by BLI, wild-type 2G12 bound the $\alpha$-configured thiourea conjugate 32 with an apparent $K_{\mathrm{D}}$ value of $46 \mathrm{nM}$, whereas the adipic amide conjugate 34 , with a significantly better substitution degree, was bound only slightly better ( 23 $\mathrm{nM})$. A similar trend was observed for the $\beta$-configured derivatives 33 and 35 with apparent $K_{\mathrm{D}}$ values of $274 \mathrm{nM}$ and $121 \mathrm{nM}$, respectively (Table 2). Hence, the avidities of the interactions between $2 \mathrm{G} 12$ and these multivalent constructs appear to be determined not only by the ligand densities of the conjugates but also, and perhaps not surprisingly, by the precise organization of the oligomannosides on the carrier molecule.

\section{CONCLUSIONS}

In this study we have undertaken a comparative evaluation of BSA conjugates prepared from a series of anomeric 3aminopropyl oligomannose spacer glycosides based on the structure of a bacterial mimetic of HIV-1 glycans. Conjugation reactions using thiourea or adipic amide linkages revealed a substantially higher coupling efficiency for the latter approach. However, when compared based on matching ligand density, the

Scheme 5. Synthesis of Tris-Alkyne Substituted Linker Derivative $24^{a}$
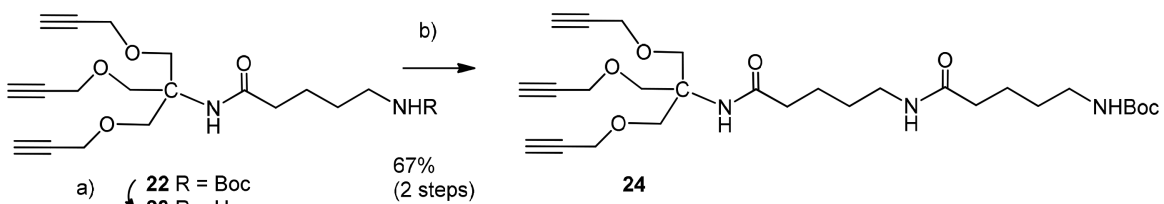

${ }^{a}$ Reagents and conditions: (a) TFA, DCM, $0{ }^{\circ} \mathrm{C}, 3 \mathrm{~h}$; (b) DMF, Boc-5-amino-pentanoic acid, NMO, HATU, rt, 16 h, $67 \%$. 
Scheme 6. Synthesis of Pentamannoside-Dendron Containing Neoglycoconjugates

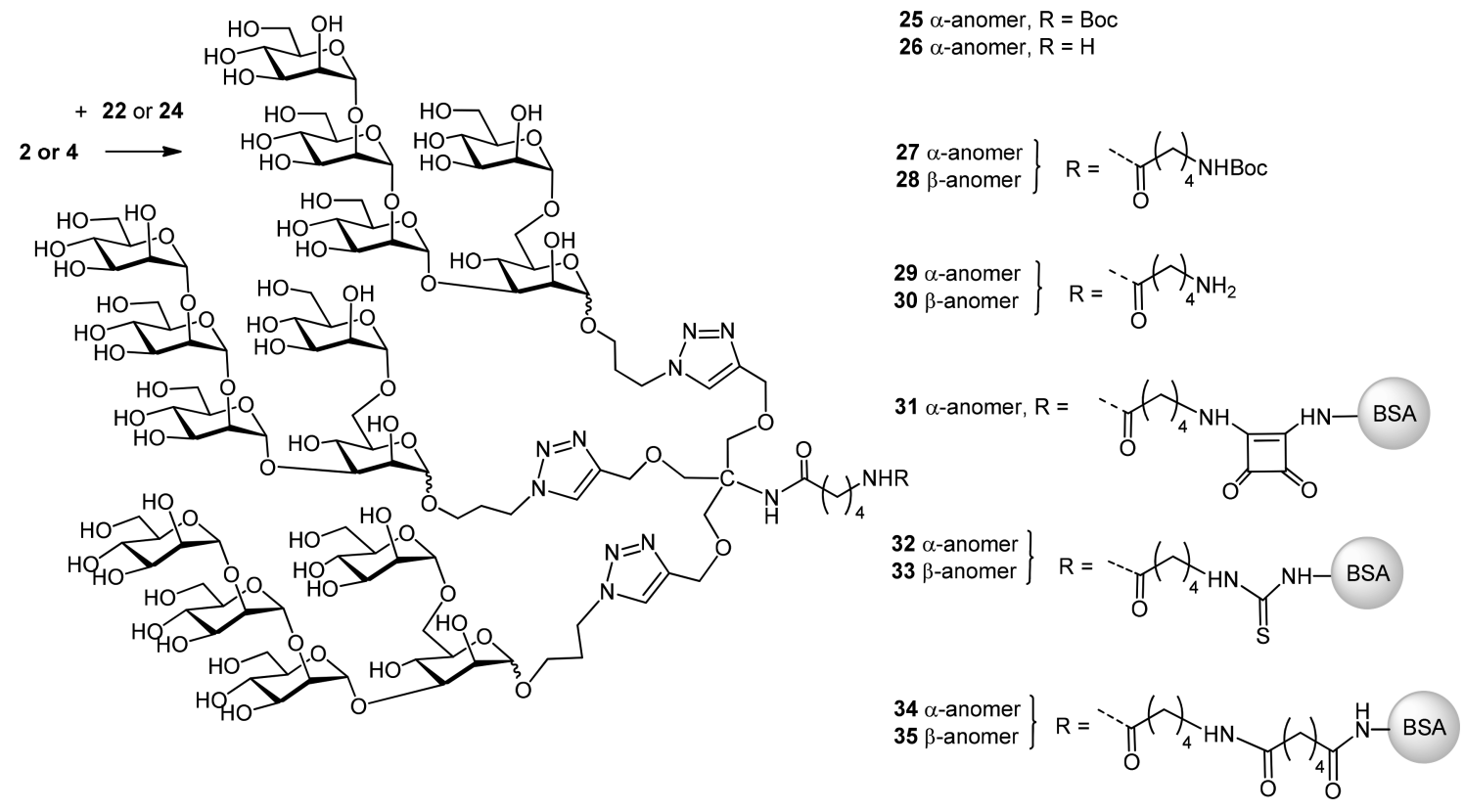

Table 3. Coupling Efficiency for Anomeric Pentamannoside Dendron Derivatives 29 and 30 to BSA

\begin{tabular}{|c|c|c|c|c|c|c|}
\hline Entry & Spacer glycoside & Protein concentration (nM) & Molar ratio & Conjugate & Ligand/BSA ratio & Efficiency $[\%]$ \\
\hline 1 & 29 & 54 & 20 & 31 & 0.5 & 2.5 \\
\hline 2 & 29 & 17 & 21 & 32 & 0.8 & 3.8 \\
\hline 3 & 30 & 10 & 21 & 33 & 0.5 & 2.4 \\
\hline 4 & 29 & 25 & 30 & 34 & 3.0 & 10.0 \\
\hline 5 & 30 & 45 & 21 & 35 & 1.3 & 6.2 \\
\hline
\end{tabular}

thiourea constructs enabled higher avidity binding of the HIVneutralizing antibody $2 \mathrm{G} 12$, with apparent $K_{\mathrm{D}}$ values in the low nanomolar range and increased avidities for conjugates with higher ligand densities. The anomeric configuration of the spacer-extended central mannose unit had a minor influence, with slightly better binding observed for ligands harboring a reducing end mannose in the $\beta$-anomeric form.

The sterically crowded ligands clustered on tris-triazole substituted scaffolds showed unexpectedly low reactivity in the conjugation reactions and inferior binding to the antibody 2 G12, illustrating the challenges in constructing antigens with appropriate spatial orientation for binding to this antibody. Further work will extend these studies to include additional antiHIV glycan-specific neutralizing antibodies, to help inform the utility of oligomannose mimicry for the elicitation of HIVneutralizing antibodies with oligomannose specificity.

\section{EXPERIMENTAL SECTION}

General Methods. Thin layer chromatography was performed on Merck precoated plates: generally, on $5 \times 10$ $\mathrm{cm}^{2}$, layer thickness $0.25 \mathrm{~mm}$, Silica Gel $60 \mathrm{~F}_{254}$; alternatively, on HPTLC plates with $2.5 \mathrm{~cm}$ concentration zone (Merck). Spots were detected by dipping reagent (anisaldehyde- $\mathrm{H}_{2} \mathrm{SO}_{4}$ ). For column chromatography silica gel $(0.040-0.063 \mathrm{~mm})$ was used. Optical rotations were measured with a PerkinElmer $243 \mathrm{~B}$ Polarimeter. $[\alpha]_{\mathrm{D}}{ }^{20}$ values are given in units of $10^{-1} \mathrm{deg} \mathrm{cm}^{2} \mathrm{~g}^{-1}$. NMR spectra were recorded on a Bruker Avance III 600 instrument $\left(600.22 \mathrm{MHz}\right.$ for ${ }^{1} \mathrm{H}, 150.93 \mathrm{MHz}$ for $\left.{ }^{13} \mathrm{C}\right)$ using standard Bruker NMR software. ${ }^{1} \mathrm{H}$ spectra were referenced to $\delta$ $=0$ using the TMS signal for solutions in $\mathrm{CDCl}_{3}$ and DSS for solutions in $\mathrm{D}_{2} \mathrm{O}$ (external calibration to 2,2-dimethyl-2silapentane-5-sulfonic acid). ${ }^{13} \mathrm{C}$ spectra were referenced to $77.00\left(\mathrm{CDCl}_{3}\right)$ and $67.40\left(\mathrm{D}_{2} \mathrm{O}\right.$, external calibration to $1,4-$ dioxane) ppm. Assignments were based on COSY, HSQC, HMBC, and TOCSY spectra. ESI-MS data were obtained on a Waters Micromass Q-TOF Ultima Global instrument. MALDIdata were obtained on a Bruker Autoflex MALDI TOF/TOF instrument using 2,5-dihydroxyacetophenone as matrix.

The following labeling of residues was used for NMR assignments:

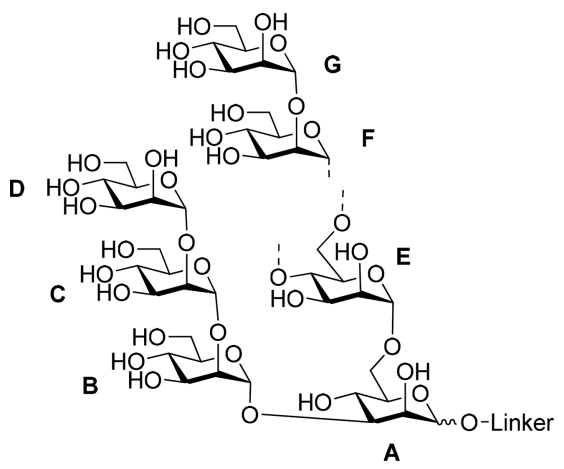

General Procedure A for Diazotransfer Reactions. To a solution of the amine ( 1 equiv) in $2: 1 \mathrm{MeOH}$-water was added $\mathrm{K}_{2} \mathrm{CO}_{3}$ (10 equiv), imidazole-1-sulfonyl azide hydrochloride (4 equiv) and a solution of $\mathrm{CuSO}_{4} \times 5 \mathrm{H}_{2} \mathrm{O}(0.1 \mathrm{M}$ in water, 0.1 equiv). The reaction mixture was stirred at room temperature for $24 \mathrm{~h}$. Subsequently the solution was filtered over Celite and the solvents were removed in vacuo. The crude product was purified using gel chromatography (Sephadex LH-20; 2:1 
water-MeOH). Product containing fractions were lyophilized yielding the corresponding azides as colorless solids.

General Procedure B for Thiourea Based Conjugation. The amine ligand $(0.002 \mathrm{mmol} ; 75$ equiv) was dissolved in 0.1 $\mathrm{M}$ aq. $\mathrm{NaHCO}_{3}(2 \mathrm{~mL})$ and a solution of thiophosgene $(2 \mathrm{~mL}$ of a $0.006 \mathrm{M}$ solution in $\mathrm{CHCl}_{3} ; 450$ equiv) was added. The biphasic mixture was stirred vigorously for $2 \mathrm{~h}$. The organic phase was removed with a pipet and the aqueous phase was extracted with $\mathrm{CHCl}_{3}$ three times. Traces of $\mathrm{CHCl}_{3}$ were removed by bubbling a stream of air through the remaining solution. The resulting aqueous phase was added to a solution of BSA ( $2 \mathrm{mg}$; $30 \mathrm{nmol} ; 1$ equiv) in buffer A ( $2 \mathrm{~mL}$ of $0.3 \mathrm{M} \mathrm{NaCl}$ and $0.1 \mathrm{M} \mathrm{NaHCO}_{3}$ ) and was stirred for $62 \mathrm{~h}$. Then the mixture was dialyzed against water three times and the residue was lyophilized yielding the product as a white solid. The amount of conjugated ligand per BSA was determined using MALDI-TOF mass spectroscopy.

General Procedure C for Adipic Acid Based Conjugation. The amine ligand was dissolved in DMSO and $N, N^{\prime}$ adipoylbis(succinimide) was added all at once followed by the addition of $\mathrm{NEt}_{3}$. The solution was stirred for $3 \mathrm{~h}$ at room temperature and then PBS-buffer $(\mathrm{pH}=7.2)$ as well as EtOAc (1 $\mathrm{mL}$ ) were added. The organic phase was removed with a pipet and the aqueous phase was washed two more times with EtOAc ( $1 \mathrm{~mL}$ each). Traces of EtOAc were removed by bubbling a stream of air through the remaining solution. The aqueous phase was subsequently added to BSA and the reaction mixture was stirred for $24 \mathrm{~h}$ at room temperature. In order to get rid of remaining free ligand and salts the crude reaction mixture was centrifuged using a spin filter (Amicon $0.5 \mathrm{M}, 30 \mathrm{kDa}$ ) for 10 $\min \left(\right.$ at $25{ }^{\circ} \mathrm{C}$ and $\left.14000 \times \mathrm{g}\right)$. The remaining solution was washed twice with PBS-buffer $\left(0.45 \mathrm{~mL}\right.$ each, $10 \mathrm{~min}$ at $25^{\circ} \mathrm{C}$ and $14000 \times \mathrm{g}$ ) and was then removed from the filter by centrifugation. Lyophilization yielded the product as white solid. The amount of conjugated ligand/BSA was determined using MALDI-TOF mass spectroscopy.

General Procedure D for Click Reactions. The azide (3.3-3.6 equiv) was dissolved in 1:1 tert $\mathrm{BuOH}-$ water under argon and $24(0.05 \mathrm{M}$ in tert $\mathrm{BuOH} ; 1$ equiv) was added, followed by the addition of $\mathrm{CuSO}_{4} \times 5 \mathrm{H}_{2} \mathrm{O}(0.05 \mathrm{M}$ in water; 1 equiv). The mixture was degassed by the freeze-pump-thaw method. Then $\mathrm{Na}$-ascorbate ( $0.05 \mathrm{M}$ in degassed water; 2 equiv) was added and the mixture was stirred at $\mathrm{rt}$ for $72 \mathrm{~h}$. The mixture was filtered and the filtrate was concentrated. The crude product was purified by gel chromatography (Sephadex LH-20; 2:1 water-MeOH). The product containing fractions were lyophilized yielding the corresponding click products as solids. The structure of the products was verified by ${ }^{1} \mathrm{H}$ NMR spectroscopy and MALDI-TOF mass spectroscopy.

General Procedure E for Boc Removal. The click-product was dissolved in 1:1 water-TFA $(1 \mathrm{~mL})$ and was stirred at $0{ }^{\circ} \mathrm{C}$ for $45 \mathrm{~min}$. The solvent was removed in vacuo yielding the product.

General Procedure F for Conjugation of Dendritic Ligands. The multivalent amine ligand was dissolved in $0.1 \mathrm{M}$ aq. $\mathrm{NaHCO}_{3}$, and a solution of thiophosgene $(0.006 \mathrm{M}$ in $\mathrm{CHCl}_{3}$ ) was added. The biphasic mixture was stirred vigorously for $2 \mathrm{~h}$. The organic phase was removed with a pipet and the aqueous phase was extracted with $\mathrm{CHCl}_{3}$ three times. Traces of $\mathrm{CHCl}_{3}$ were removed by bubbling a stream of air through the remaining solution. The resulting aqueous phase was added to a solution of BSA in buffer $\mathrm{A}\left(0.3 \mathrm{M} \mathrm{NaCl}\right.$ and $\left.0.1 \mathrm{M} \mathrm{NaHCO}_{3}\right)$ and was stirred for $62 \mathrm{~h}$. In order to get rid of remaining free ligand and salts the reaction mixture was centrifuged using a spin filter (Amicon $0.5 \mathrm{M}, 30 \mathrm{kDa}$ ) for $10 \mathrm{~min}$ (at $25^{\circ} \mathrm{C}$ and $14000 \times$ $\mathrm{g})$. The remaining solution was washed twice with water $(0.45$ $\mathrm{mL}$ each, $10 \mathrm{~min}$ at $25{ }^{\circ} \mathrm{C}$ and $14000 \times \mathrm{g}$ ) and was then removed from the filter by centrifugation. Lyophilization yielded the product as white solid. The amount of conjugated ligand/ BSA was determined using MALDI-TOF mass spectroscopy.

Site-Directed Mutagenesis and Construction of $\mathrm{mAb}$ Expression Vectors. The sequences encoding the $2 \mathrm{G} 12$ heavy and light chains (omitting their authentic signal peptides) were amplified from the corresponding pDONR221 constructs ${ }^{50}$ by PCR using the primer combinations 2G12HC_BsaI_fw/ 2G12HC_BsaI_rv and 2G12LC_BsaI_fw/2G12LC_BsaI_rv

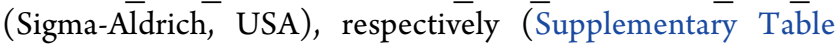
$S 1$ ). The fragments thus generated were then inserted into the $B s a \mathrm{I}$ sites of $\mathrm{pICH} \alpha 31160$ (heavy chain) and $\mathrm{pICH} \alpha 26033$ (light chain) as described. ${ }^{51,52}$ The domain-swapping point mutation $\mathrm{I}_{19 \mathrm{R}^{40}}$ was introduced into the $2 \mathrm{G} 12$ heavy-chain sequence by QuikChange site-directed mutagenesis (Agilent Technologies, USA) with the complementary primer pair 2G12HC_I19R_fw and 2G12HC_I19R_rv (Supplementary Table S1) and $\bar{P}$ husion DNA polymerase (Thermo Scientific, USA), using pDONR221-2G12 $\mathrm{HC}^{50}$ as template. The mutated product was then cloned into $\mathrm{PICH} \alpha 31160$ as outlined above. The fidelity of all wild-type and mutant $2 \mathrm{G} 12$ sequences was verified (Microsynth, Switzerland). For agroinfiltration of Nicotiana benthamiana, all constructs were transformed into the Agrobacterium tumefaciens strain GV3101::pMP90.

Expression of mAbs in $N$. benthamiana. $N$. benthamiana $\Delta \mathrm{XT} / \mathrm{FT}$ plants lacking plant-specific $\alpha 1,3$-fucosylation and $\beta 1,2$-xylosylation were grown for $4-5$ weeks at $24^{\circ} \mathrm{C}$ with a $16 \mathrm{~h}$ light: $8 \mathrm{~h}$ dark photoperiod. Infiltration with agrobacteria carrying the respective $\mathrm{mAb}$ expression vectors was then performed as reported previously. ${ }^{53}$ Briefly, overnight cultures were pelleted and then resuspended in infiltration buffer $(25$ $\mathrm{mM}$ Mes buffer ( $\mathrm{pH}$ 5.6), $25 \mathrm{mM} \mathrm{MgSO}_{4}, 0.1 \mathrm{mM}$ acetosyringone) at an $\mathrm{OD}_{600}$ of $0.2\left(1.0 \mathrm{OD}_{600}\right.$ corresponds to $5 \times 10^{8}$ cells $/ \mathrm{mL}$ ). Equal amounts of the strains carrying the respective heavy and light chain constructs were used. Infiltrated $N$. benthamiana leaves were harvested after 4-5 days.

Purification of mAbs Produced in $N$. benthamiana Leaves. Antibody extraction and purification was performed as described previously, with minor modifications. ${ }^{41,43}$ Briefly, infiltrated leaf material was homogenized under liquid nitrogen and extracted with $0.1 \mathrm{M}$ Tris $/ \mathrm{HCl}(\mathrm{pH} 7.0)$ containing $0.5 \mathrm{M}$ $\mathrm{NaCl}, 40 \mathrm{mM}$ ascorbic acid and $1 \mathrm{mM}$ EDTA $(2 \mathrm{~mL}$ per gram leaf wet weight). The extract was clarified by a series of centrifugation and filtration steps. Antibodies were then purified by affinity chromatography on a column packed with $1 \mathrm{~mL}$ rProtein A Sepharose 4 Fast Flow (GE Healthcare, UK), using $0.1 \mathrm{M}$ glycine $/ \mathrm{HCl}(\mathrm{pH}$ 3.0) for elution. Protein-containing eluate fractions were immediately neutralized by addition of 0.1 $\mathrm{M}$ Tris/ $\mathrm{HCl}$ ( $\mathrm{pH} 8.0$ ), dialyzed against PBS containing $0.02 \%$ $(\mathrm{v} / \mathrm{v}) \mathrm{NaN}_{3}$ and then concentrated by ultrafiltration using Amicon YM30 centrifugal filter units (Merck, Germany).

ELISA. Enzyme-linked immunosorbent assay (ELISA) plates (96-well) were coated with $500 \mathrm{ng}$ per well of HIV-1 92UG37 gp140 (Polymun Scientific, Austria), manufactured in CHO cells, or the respective conjugate in PBS for $16 \mathrm{~h}$ at $4{ }^{\circ} \mathrm{C}$ and then washed with PBS containing $0.05 \%$ Tween 20 (PBST). In the case of $2 \mathrm{G} 12-\mathrm{I} 19 \mathrm{R}$, antibody $(20 \mu \mathrm{g} / \mathrm{mL})$ was precomplexed with Fc-specific goat antihuman IgG $\mathrm{F}\left(\mathrm{ab}^{\prime}\right)_{2}$ fragments $(10 \mu \mathrm{g} /$ $\mathrm{mL}$; Sigma-Aldrich) for $15 \mathrm{~min}$ at $4{ }^{\circ} \mathrm{C}$. Samples were serially 
diluted (1:2) in PBST containing 1\% BSA (dilution buffer) prior to addition to the wells. After incubation for $1 \mathrm{~h}$ and subsequent washing, bound antibodies were detected with $0.1 \mu \mathrm{g} / \mathrm{mL}$ goat antihuman kappa chain peroxidase conjugate (Sigma-Aldrich) in dilution buffer. After $1 \mathrm{~h}$, plates were washed and then

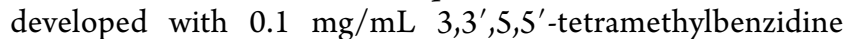
(Sigma-Aldrich) and $0.006 \% \mathrm{H}_{2} \mathrm{O}_{2}$ in $35 \mathrm{mM}$ citric acid/65 $\mathrm{mM}$ sodium phosphate ( $\mathrm{pH} 5.0)$ for $15 \mathrm{~min}$. Reactions were quenched by addition of $90 \mathrm{mM} \mathrm{H}_{2} \mathrm{SO}_{4}$ prior to analysis by spectrophotometry at $450 \mathrm{~nm}$. All steps were performed at room temperature unless stated otherwise.

Bio-Layer Interferometry. All biolayer interferometry assays were performed on a ForteBio Octet QK system (Pall ForteBio) equipped with protein A biosensor tips (Pall ForteBio, Cat. No. 18-5010). The assay was performed at 30 ${ }^{\circ} \mathrm{C}$ in kinetics buffer (Pall ForteBio). HIV-1 antiglycan antibody 2G12 (Polymun Scientific, Austria) was immobilized onto protein A biosensors at $10 \mu \mathrm{g} / \mathrm{mL}$ for $60 \mathrm{~s}$. Glycoconjugate samples were prepared in concentrations of $16-1000 \mu \mathrm{g} / \mathrm{mL}$ and $k_{\text {on }}$ and $k_{\text {off }}$ were measured, monitoring association (600 s) and dissociation (1200 s) in kinetics buffer. HIV-1 gp140 (250 $\mu \mathrm{g} / \mathrm{mL}$, corresponding to $3.5 \mu \mathrm{M}$ ) was used as positive control. BSA served as negative control. Data were processed and analyzed with the Octet data analysis software 6.4 (ForteBio) using a 1:1 binding model, which was chosen because the bivalent model gave very poor fits.

3-Azido-1-propyl $\alpha$-D-mannopyranosyl- $(1 \rightarrow 2)-\alpha$-D-mannopyranosyl-(1 $\rightarrow$ 2)- $\alpha$-D-mannopyranosyl- $(1 \rightarrow 3)-[\alpha-D-$ mannopyranosyl-(1 $\rightarrow$ 6)]- $\alpha$-D-mannopyranoside (2). Compound $\mathbf{2}$ was synthesized according to general procedure A using the following amounts: Compound $\mathbf{1}$ ( $38 \mathrm{mg} ; 0.043 \mathrm{mmol})$ in 2:1 $\mathrm{MeOH}$-water $(3 \mathrm{~mL}), \mathrm{K}_{2} \mathrm{CO}_{3}(59 \mathrm{mg} ; 0.43 \mathrm{mmol})$, imidazole-1-sulfonyl azide hydrochloride (36 $\mathrm{mg} ; 0.172 \mathrm{mmol}$ ) and a solution of $\mathrm{CuSO}_{4} \times 5 \mathrm{H}_{2} \mathrm{O}(0.1 \mathrm{M}$ in water; $10 \mu \mathrm{L} ; 4$ $\mu \mathrm{mol})$. Compound 2 was obtained as colorless solid (38 mg; 97\%); ${ }^{1} \mathrm{H}$ NMR $\left(600 \mathrm{MHz}, \mathrm{D}_{2} \mathrm{O}\right): \delta=5.31(\mathrm{~d}, J=1.3 \mathrm{~Hz}, 1 \mathrm{H}$, $\left.\mathrm{H}-1^{\mathrm{B}}\right), 5.26\left(\mathrm{~d}, J=1.6 \mathrm{~Hz}, 1 \mathrm{H}, \mathrm{H}-1^{\mathrm{C}}\right), 5.01(\mathrm{~d}, J=1.6 \mathrm{~Hz}, 1 \mathrm{H}$, $\left.\mathrm{H}-1^{\mathrm{D}}\right), 4.87\left(\mathrm{~d}, J=1.6 \mathrm{~Hz}, 1 \mathrm{H}, \mathrm{H}-1^{\mathrm{E}}\right), 4.79(\mathrm{~s}, J=1.6 \mathrm{~Hz}, 1 \mathrm{H}, \mathrm{H}-$ $\left.1^{\mathrm{A}}\right), 4.07-4.06\left(\mathrm{~m}, 2 \mathrm{H}, \mathrm{H}-2^{\mathrm{C}}, \mathrm{H}-2^{\mathrm{A}}\right), 4.04(\mathrm{dd}, J=1.7,3.2 \mathrm{~Hz}, 1$ $\left.\mathrm{H}, \mathrm{H}-2^{\mathrm{B}}\right), 4.03\left(\mathrm{~J}=1.8,3.2 \mathrm{~Hz}, 1 \mathrm{H}, \mathrm{H}-2^{\mathrm{D}}\right), 3.97-3.94(\mathrm{~m}, 3 \mathrm{H}$, $\left.\mathrm{H}-3^{\mathrm{B}}, \mathrm{H}-2^{\mathrm{E}}, \mathrm{H}-6 \mathrm{a}^{\mathrm{A}}\right), 3.92\left(\mathrm{dd}, J=3.2,9.4 \mathrm{~Hz}, 1 \mathrm{H}, \mathrm{H}-3^{\mathrm{C}}\right), 3.87-$ $3.53(\mathrm{~m}, 25 \mathrm{H}), 3.45-3.38\left(\mathrm{~m}, 2 \mathrm{H}, \mathrm{CH}_{2} \mathrm{CH}_{2} \mathrm{~N}_{3}\right), 1.91-1.82$ $\left(\mathrm{m}, 2 \mathrm{H}, \mathrm{CH}_{2} \mathrm{CH}_{2} \mathrm{~N}_{3}\right) ;{ }^{13} \mathrm{C} \mathrm{NMR}\left(125 \mathrm{MHz}, \mathrm{D}_{2} \mathrm{O}\right): \delta=103.0$ $\left(\mathrm{C}-1^{\mathrm{D}}\right), 101.6\left(\mathrm{C}-1^{\mathrm{B}}\right), 101.5\left(\mathrm{C}-1^{\mathrm{C}}\right), 100.7\left(\mathrm{C}-1^{\mathrm{A}}\right), 100.2(\mathrm{C}-$ $\left.1^{\mathrm{E}}\right), 79.6\left(\mathrm{C}-3^{\mathrm{A}}\right), 79.5\left(\mathrm{C}-2^{\mathrm{B}}\right), 79.3\left(\mathrm{C}-2^{\mathrm{C}}\right), 75.0\left(\mathrm{C}-5^{\mathrm{A}}\right), 74.1$, 74.0 (d.i.), $73.5\left(\mathrm{C}-5^{\mathrm{B}}, \mathrm{C}-5^{\mathrm{C}}, \mathrm{C}-5^{\mathrm{D}}, \mathrm{C}-5^{\mathrm{E}}\right), 71.9,71.4,71.1,70.9$, $70.8(3 \mathrm{C})$ and $70.5\left(7 \mathrm{C}, \mathrm{C}-2^{\mathrm{A}}, \mathrm{C}-2^{\mathrm{E}}, \mathrm{C}-2^{\mathrm{D}}, \mathrm{C}-3^{\mathrm{E}}, \mathrm{C}-3^{\mathrm{B}}, \mathrm{C}-3^{\mathrm{C}}, \mathrm{C}-\right.$ $\left.3^{\mathrm{D}}\right), 67.8,67.7,67.6$, and $67.5\left(\mathrm{C}-4^{\mathrm{B}}, \mathrm{C}-4^{\mathrm{C}}, \mathrm{C}-4^{\mathrm{D}}, \mathrm{C}-4^{\mathrm{E}}\right), 65.5(\mathrm{C}-$ $\left.4^{\mathrm{A}}\right), 66.2\left(\mathrm{C}-6^{\mathrm{A}}\right), 65.7\left(\mathrm{OCH}_{2} \mathrm{CH}_{2}\right), 61.9$ and $61.8\left(4 \mathrm{C}, \mathrm{C}-6^{\mathrm{B}}\right.$, $\left.\mathrm{C}-6^{\mathrm{C}}, \mathrm{C}-6^{\mathrm{D}}, \mathrm{C}-6^{\mathrm{E}}\right), 49.0\left(\mathrm{CH}_{2} \mathrm{CH}_{2} \mathrm{~N}_{3}\right), 28.6\left(\mathrm{CH}_{2} \mathrm{CH}_{2} \mathrm{~N}_{3}\right)$. ESITOF HRMS: $m / z$ calcd for $\mathrm{C}_{33} \mathrm{H}_{57} \mathrm{~N}_{3} \mathrm{O}_{26}\left[\mathrm{M}+\mathrm{NH}_{4}{ }^{+}\right]^{+}$: 929.3569; found: 929.3585 .

3-Azido-1-propyl $\alpha$-D-mannopyranosyl-(1 $\rightarrow 2)-\alpha$-D-mannopyranosyl- $(1 \rightarrow 2)-\alpha$-D-mannopyranosyl- $(1 \rightarrow 3)-[\alpha-D-$ mannopyranosyl- $(1 \rightarrow 6)]-\beta$-D-mannopyranoside (4). Compound 4 was synthesized according to general procedure A using the following amounts: Compound $3(5.0 \mathrm{mg} ; 0.006 \mathrm{mmol})$ in 2:1 $\mathrm{MeOH}$-water $(1 \mathrm{~mL}), \mathrm{K}_{2} \mathrm{CO}_{3}(6.0 \mathrm{mg} ; 0.043 \mathrm{mmol})$, imidazole-1-sulfonyl azide hydrochloride $(5.0 \mathrm{mg} ; 0.024 \mathrm{mmol})$ and a solution of $\mathrm{CuSO}_{4} \times 5 \mathrm{H}_{2} \mathrm{O}(0.1 \mathrm{M}$ in water; $4 \mu \mathrm{L} ; 0.4$ $\mu \mathrm{mol})$. Compound 4 was obtained as colorless solid $(4.7 \mathrm{mg}$; 91\%); ${ }^{1} \mathrm{H}$ NMR $\left(600 \mathrm{MHz}, \mathrm{D}_{2} \mathrm{O}\right): \delta=5.30(\mathrm{~d}, J=1.4 \mathrm{~Hz}, 1 \mathrm{H}$, $\left.\mathrm{H}-1^{\mathrm{B}}\right), 5.27\left(\mathrm{~d}, J=1.7 \mathrm{~Hz}, 1 \mathrm{H}, \mathrm{H}-1^{\mathrm{C}}\right), 5.01(\mathrm{~d}, J=1.7 \mathrm{~Hz}, 1 \mathrm{H}$,
$\left.\mathrm{H}-1^{\mathrm{D}}\right), 4.88\left(\mathrm{~d}, J=1.6 \mathrm{~Hz}, 1 \mathrm{H}, \mathrm{H}-1^{\mathrm{E}}\right), 4.64\left(\mathrm{~s}, 1 \mathrm{H}, \mathrm{H}-1^{\mathrm{A}}\right), 4.10$ (br d, $J=3.2 \mathrm{~Hz}, 1 \mathrm{H}, \mathrm{H}-2^{\mathrm{A}}$ ), 4.07 (dd, $J=1.9,3.1 \mathrm{~Hz}, 1 \mathrm{H}, \mathrm{H}-$ $\left.2^{\mathrm{C}}\right), 4.04\left(\mathrm{dd}, J=1.7,3.2 \mathrm{~Hz}, 1 \mathrm{H}, \mathrm{H}-2^{\mathrm{B}}\right), 4.03(\mathrm{dd}, J=1.8,3.3$ $\left.\mathrm{Hz}, 1 \mathrm{H}, \mathrm{H}-2^{\mathrm{D}}\right), 3.97-3.58(\mathrm{~m}, 29 \mathrm{H}), 3.51(\mathrm{ddd}, J=1.8,5.0,9.8$ $\left.\mathrm{Hz}, 1 \mathrm{H}, \mathrm{H}-5^{\mathrm{A}}\right), 3.40\left(\mathrm{t}, J=6.7 \mathrm{~Hz}, 2 \mathrm{H}, \mathrm{CH}_{2} \mathrm{CH}_{2} \mathrm{~N}_{3}\right), 1.88-1.84$ $\left(\mathrm{m}, 2 \mathrm{H}, \mathrm{CH}_{2} \mathrm{CH}_{2} \mathrm{~N}_{3}\right) \cdot{ }^{13} \mathrm{C} \mathrm{NMR}\left(125 \mathrm{MHz}, \mathrm{D}_{2} \mathrm{O}\right.$, selected data from HSQC-experiments): $\delta=102.9\left(\mathrm{C}-1^{\mathrm{D}}\right), 101.4\left(\mathrm{C}-1^{\mathrm{B}}\right)$, $101.3\left(\mathrm{C}-1^{\mathrm{C}}\right), 100.6\left(\mathrm{C}-1^{\mathrm{A}}\right), 100.1\left(\mathrm{C}-1^{\mathrm{E}}\right), 81.6\left(\mathrm{C}-3^{\mathrm{A}}\right), 79.3(\mathrm{C}-$ $\left.2^{\mathrm{B}}\right), 79.2\left(\mathrm{C}-2^{\mathrm{C}}\right), 74.8\left(\mathrm{C}-5^{\mathrm{A}}\right), 67.6\left(\mathrm{OCH}_{2} \mathrm{CH}_{2}\right), 66.5\left(\mathrm{C}-4^{\mathrm{A}}\right)$, $66.3\left(\mathrm{C}-6^{\mathrm{A}}\right), 48.8\left(\mathrm{CH}_{2} \mathrm{CH}_{2} \mathrm{~N}_{3}\right)$. ESI-TOF HRMS: $m / z$ calcd for $\mathrm{C}_{33} \mathrm{H}_{57} \mathrm{~N}_{3} \mathrm{O}_{26}\left[\mathrm{M}+\mathrm{NH}_{4}^{+}\right]^{+}$: 929.3569 ; found: 929.3569 .

3-Azido-1-propyl $\alpha$-D-mannopyranosyl-(1 $\rightarrow 2)$ - $\alpha$-D-mannopyranosyl-(1 $\rightarrow$ 2)- $\alpha$-D-mannopyranosyl- $(1 \rightarrow 3)-[\alpha-D-$ mannopyranosyl- $(1 \rightarrow 2)-\alpha$-D-mannopyranosyl- $(1 \rightarrow 6)-\alpha-D-$ mannopyranosyl-(1 $\rightarrow$ 6)- $\alpha$-D-mannopyranoside (6). Compound 6 was synthesized according to general procedure A using following amounts: Compound $\mathbf{5}(8.0 \mathrm{mg} ; 0.006 \mathrm{mmol})$ in $2: 1$ $\mathrm{MeOH}$-water $(1 \mathrm{~mL}), \mathrm{K}_{2} \mathrm{CO}_{3}(9.0 \mathrm{mg} ; 0.062 \mathrm{mmol})$, imidazole1-sulfonyl azide hydrochloride $(5.0 \mathrm{mg} ; 0.025 \mathrm{mmol})$ and a solution of $\mathrm{CuSO}_{4} \times 5 \mathrm{H}_{2} \mathrm{O}(0.1 \mathrm{M}$ in water; $6 \mu \mathrm{L} ; 0.6 \mu \mathrm{mol})$. Compound 6 was obtained as colorless solid $(6.0 \mathrm{mg} ; 84 \%) ;{ }^{1} \mathrm{H}$ $\operatorname{NMR}\left(600 \mathrm{MHz}, \mathrm{D}_{2} \mathrm{O}\right): \delta=5.30\left(\mathrm{~d}, J=1.3 \mathrm{~Hz}, 1 \mathrm{H}, \mathrm{H}-1^{\mathrm{B}}\right), 5.27$ $\left(\mathrm{d}, J=1.5 \mathrm{~Hz}, 1 \mathrm{H}, \mathrm{H}-1^{\mathrm{C}}\right), 5.11\left(\mathrm{~d}, J=1.4 \mathrm{~Hz}, 1 \mathrm{H}, \mathrm{H}-1^{\mathrm{F}}\right), 5.01$ $\left(\mathrm{d}, J=1.8 \mathrm{~Hz}, 1 \mathrm{H}, \mathrm{H}-1^{\mathrm{D}}\right.$ or $\left.\mathrm{H}-1^{\mathrm{G}}\right)$ and $5.00(\mathrm{~d}, J=1.7 \mathrm{~Hz}, 1 \mathrm{H}$, $\mathrm{H}-1^{\mathrm{D}}$ or $\left.\mathrm{H}-1^{\mathrm{G}}\right), 4.86\left(\mathrm{~d}, J=1.3 \mathrm{~Hz}, 1 \mathrm{H}, \mathrm{H}-1^{\mathrm{E}}\right), 4.79(\mathrm{~d}, J=1.5$ $\left.\mathrm{Hz}, 1 \mathrm{H}, \mathrm{H}-1^{\mathrm{A}}\right), 4.08-4.06\left(\mathrm{~m}, 2 \mathrm{H}, \mathrm{H}-2^{\mathrm{A}}, \mathrm{H}-2^{\mathrm{C}}\right), 4.05-4.02(\mathrm{~m}$, $\left.3 \mathrm{H}, \mathrm{H}-2^{\mathrm{B}}, \mathrm{H}-2^{\mathrm{D}}, \mathrm{H}-2^{\mathrm{G}}\right), 3.98\left(\mathrm{dd}, J=1.7,3.2 \mathrm{~Hz}, 1 \mathrm{H}, \mathrm{H}-2^{\mathrm{F}}\right)$, $3.97-3.53(\mathrm{~m}, 38 \mathrm{H}), 3.45-3.38\left(\mathrm{~m}, 2 \mathrm{H}, \mathrm{CH}_{2} \mathrm{CH}_{2} \mathrm{~N}_{3}\right), 1.91-$ $1.82\left(\mathrm{~m}, 2 \mathrm{H}, \mathrm{CH}_{2} \mathrm{CH}_{2} \mathrm{~N}_{3}\right) ;{ }^{13} \mathrm{C} \mathrm{NMR}\left(150 \mathrm{MHz}, \mathrm{D}_{2} \mathrm{O}\right.$, selected signals form HSQC-experiments): $\delta=102.9\left(2 \mathrm{C}, \mathrm{C}-1^{\mathrm{D}}, \mathrm{C}-1^{\mathrm{G}}\right)$, $101.5\left(2 \mathrm{C}, \mathrm{C}-1^{\mathrm{B}}, \mathrm{C}-1^{\mathrm{C}}\right), 100.6\left(\mathrm{C}-1^{\mathrm{A}}\right), 100.2\left(\mathrm{C}-1^{\mathrm{E}}\right), 98.8(\mathrm{C}-$ $\left.1^{\mathrm{F}}\right), 79.6\left(\mathrm{C}-3^{\mathrm{A}}\right), 66.6\left(\mathrm{C}-6^{\mathrm{A}}\right), 65.6\left(\mathrm{OCH}_{2}\right), 48.8$ $\left(\mathrm{CH}_{2} \mathrm{CH}_{2} \mathrm{~N}_{3}\right)$; ESI-TOF HRMS: $m / z$ calcd for $\mathrm{C}_{45} \mathrm{H}_{77} \mathrm{~N}_{3} \mathrm{O}_{36}$ $\left[\mathrm{M}+\mathrm{NH}_{4}^{+}\right]^{+}$: 1253.4625; found: 1253.4647 .

3-Azido-1-propyl $\alpha$-D-mannopyranosyl- $(1 \rightarrow 2)-\alpha$-D-mannopyranosyl- $(1 \rightarrow 2)-\alpha$-D-mannopyranosyl- $(1 \rightarrow 3)-[\alpha-D-$ mannopyranosyl-(1 $\rightarrow$ 2)- $\alpha$-D-mannopyranosyl- $(1 \rightarrow 6)-\alpha-D-$ mannopyranosyl-(1 $\rightarrow$ 6)- $\beta$-D-mannopyranoside (8). Compound 8 was synthesized according to General procedure A using following amounts: Compound $7(5.0 \mathrm{mg} ; 0.004 \mathrm{mmol})$ in 2:1 $\mathrm{MeOH}$-water $(1 \mathrm{~mL}), \mathrm{K}_{2} \mathrm{CO}_{3}(5.6 \mathrm{mg} ; 0.04 \mathrm{mmol})$, imidazole-1-sulfonyl azide hydrochloride $(0.0034 \mathrm{~g} ; 0.016$ mmol; 4 equiv) and a solution of $\mathrm{CuSO}_{4} \times 5 \mathrm{H}_{2} \mathrm{O}(0.1 \mathrm{M}$ in water; $4 \mu \mathrm{L} ; 0.4 \mu \mathrm{mol})$. Compound 8 was obtained as colorless solid (4.4 mg; 90\%); ${ }^{1} \mathrm{H}$ NMR $\left(600 \mathrm{MHz}, \mathrm{D}_{2} \mathrm{O}\right): \delta=5.30(\mathrm{~d}, J=$ $\left.1.5 \mathrm{~Hz}, 1 \mathrm{H}, \mathrm{H}-1^{\mathrm{B}}\right), 5.27\left(\mathrm{~d}, J=1.4 \mathrm{~Hz}, 1 \mathrm{H}, \mathrm{H}-1^{\mathrm{C}}\right), 5.11(\mathrm{~d}, J=$ $\left.1.4 \mathrm{~Hz}, 1 \mathrm{H}, \mathrm{H}-1^{\mathrm{F}}\right), 5.01$ and $5.00(2 \mathrm{~d}, J=1.8 \mathrm{~Hz}$, each $1 \mathrm{H}, \mathrm{H}-$ $\left.1^{\mathrm{D}}, \mathrm{H}-1^{\mathrm{G}}\right), 4.87\left(\mathrm{~d}, J=1.4 \mathrm{~Hz}, 1 \mathrm{H}, \mathrm{H}-1^{\mathrm{E}}\right), 4.64\left(\mathrm{br} \mathrm{s}, 1 \mathrm{H}, \mathrm{H}-1^{\mathrm{A}}\right)$, $4.11\left(\mathrm{br} \mathrm{d}, J=3.2 \mathrm{~Hz}, 1 \mathrm{H}, \mathrm{H}-2^{\mathrm{A}}\right.$ ), 4.07 (dd, $J=1.8,3.2 \mathrm{~Hz}, 1 \mathrm{H}$, $\left.\mathrm{H}-2^{\mathrm{C}}\right), 4.05\left(\mathrm{dd}, J=1.8,3.1 \mathrm{~Hz}, 1 \mathrm{H}, \mathrm{H}-2^{\mathrm{B}}\right), 4.04$ and $4.03(2 \mathrm{x}$ $\mathrm{dd}, J=1.8,3.3 \mathrm{~Hz}$, each $\left.1 \mathrm{H}, \mathrm{H}-2^{\mathrm{D}}, \mathrm{H}-2^{\mathrm{G}}\right), 3.99-3.58(\mathrm{~m}, 38 \mathrm{H})$ $3.51\left(\mathrm{ddd}, J=1.8,4.9,9.8 \mathrm{~Hz}, 1 \mathrm{H}, \mathrm{H}-5^{\mathrm{A}}\right), 3.40(\mathrm{t}, J=6.7 \mathrm{~Hz}, 2$ $\left.\mathrm{H}, \mathrm{CH}_{2} \mathrm{CH}_{2} \mathrm{~N}_{3}\right), 1.88-1.83\left(\mathrm{~m}, 2 \mathrm{H}, \mathrm{CH}_{2} \mathrm{CH}_{2} \mathrm{~N}_{3}\right) ;{ }^{13} \mathrm{C} \mathrm{NMR}$ (150 MHz, $\mathrm{D}_{2} \mathrm{O}$, selected signals from HSQC-experiments): $\delta=$ $103.0\left(\mathrm{C}-1^{\mathrm{D}}, \mathrm{C}-1^{\mathrm{G}}\right), 101.4\left(\mathrm{C}-1^{\mathrm{B}}\right), 101.3\left(\mathrm{C}-1^{\mathrm{C}}\right), 100.6\left(\mathrm{C}-1^{\mathrm{A}}\right)$, $100.3\left(\mathrm{C}-1^{\mathrm{E}}\right), 98.8\left(\mathrm{C}-1^{\mathrm{F}}\right), 81.7\left(\mathrm{C}-3^{\mathrm{A}}\right), 74.7\left(\mathrm{C}-5^{\mathrm{A}}\right), 48.8$ $\left(\mathrm{CH}_{2} \mathrm{CH}_{2} \mathrm{~N}_{3}\right)$. ESI-TOF HRMS: $m / z$ calcd for $\mathrm{C}_{45} \mathrm{H}_{77} \mathrm{~N}_{3} \mathrm{O}_{36}$ $\left[\mathrm{M}+\mathrm{H}^{+}\right]^{+}$: 1236.4360; found: 1236.4410 .

3-Azido-1-propyl $\alpha$-D-mannopyranosyl-(1 $\rightarrow 2)-\alpha$-D-mannopyranosyl-(1 $\rightarrow$ 2)- $\alpha$-D-mannopyranosyl- $(1 \rightarrow 3)-[\alpha-D-$ mannopyranosyl-(1 $\rightarrow$ 2)- $\alpha$-D-mannopyranosyl- $(1 \rightarrow 4)-\alpha-D-$

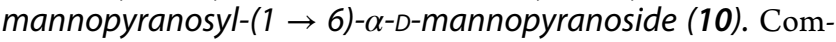
pound 2 was synthesized according to general procedure A using 
the following amounts: 9 (7.0 mg; $0.006 \mathrm{mmol})$ in $2: 1 \mathrm{MeOH}$ water $(1 \mathrm{~mL}), \mathrm{K}_{2} \mathrm{CO}_{3}(8.0 \mathrm{mg} ; 0.058 \mathrm{mmol})$, imidazole-1sulfonyl azide hydrochloride $(5.0 \mathrm{mg} ; 0.023 \mathrm{mmol})$ and a solution of $\mathrm{CuSO}_{4} \times 5 \mathrm{H}_{2} \mathrm{O}(0.1 \mathrm{M}$ in water; $6 \mu \mathrm{L} ; 0.6 \mu \mathrm{mol})$. 10 was obtained as colorless solid (6.5 mg; 91\%); ${ }^{1} \mathrm{H}$ NMR (600 $\left.\mathrm{MHz}, \mathrm{D}_{2} \mathrm{O}\right): \delta=5.45\left(\mathrm{~d}, J=1.6 \mathrm{~Hz}, 1 \mathrm{H}, \mathrm{H}-1^{\mathrm{F}}\right), 5.31(\mathrm{~d}, J=1.6$ $\left.\mathrm{Hz}, 1 \mathrm{H}, \mathrm{H}-1^{\mathrm{B}}\right), 5.27\left(\mathrm{~d}, J=1.7 \mathrm{~Hz}, 1 \mathrm{H}, \mathrm{H}-1^{\mathrm{C}}\right), 5.01$ and 5.00 $\left(2 \mathrm{~d}, J=1.7 \mathrm{~Hz}, 2 \mathrm{H}, \mathrm{H}-1^{\mathrm{G}}, \mathrm{H}-1^{\mathrm{D}}\right), 4.86\left(\mathrm{~d}, J=1.6 \mathrm{~Hz}, 1 \mathrm{H}, \mathrm{H}_{-1}{ }^{\mathrm{E}}\right)$, $4.79\left(\mathrm{~d}, J=1.6 \mathrm{~Hz}, 1 \mathrm{H}, \mathrm{H}-1^{\mathrm{A}}\right), 4.07-4.02\left(\mathrm{~m}, 6 \mathrm{H}, \mathrm{H}-2^{\mathrm{A}}, \mathrm{H}-2^{\mathrm{C}}\right.$, $\left.\mathrm{H}-2^{\mathrm{B}}, \mathrm{H}-2^{\mathrm{F}}, \mathrm{H}-2^{\mathrm{D}}, \mathrm{H}-2^{\mathrm{G}}\right), 3.97-3.55(\mathrm{~m}, 39 \mathrm{H}), 3.46-3.39(\mathrm{~m}, 2$ $\left.\mathrm{H}, \mathrm{CH}_{2} \mathrm{CH}_{2} \mathrm{~N}_{3}\right), 1.92-1.84\left(\mathrm{~m}, 2 \mathrm{H}, \mathrm{CH}_{2} \mathrm{CH}_{2} \mathrm{~N}_{3}\right) ;{ }^{13} \mathrm{C} \mathrm{NMR}$ (150 MHz, $\mathrm{D}_{2} \mathrm{O}$, selected data from HSQC-experiments): $\delta=$ $102.8\left(2 \mathrm{C}, \mathrm{C}-1^{\mathrm{D}}, \mathrm{C}-1^{\mathrm{G}}\right), 101.4\left(\mathrm{C}-1^{\mathrm{B}}\right), 101.3\left(\mathrm{C}-1^{\mathrm{C}}\right), 100.7(\mathrm{C}-$ $\left.1^{\mathrm{F}}\right), 100.5\left(\mathrm{C}-1^{\mathrm{A}}\right), 99.9\left(\mathrm{C}-1^{\mathrm{E}}\right), 66.3\left(\mathrm{OCH}_{2} \mathrm{CH}_{2}\right), 65.5\left(\mathrm{C}-6^{\mathrm{A}}\right)$, $48.7\left(\mathrm{CH}_{2} \mathrm{CH}_{2} \mathrm{~N}_{3}\right)$. ESI-TOF HRMS: $m / z$ calcd for $\mathrm{C}_{45} \mathrm{H}_{77} \mathrm{~N}_{3} \mathrm{O}_{36}\left[\mathrm{M}+\mathrm{H}^{+}\right]^{+}$: 1236.4360; found: 1236.4412 .

3-Azido-1-propyl $\alpha$-D-mannopyranosyl-(1 $\rightarrow 2)-\alpha$-D-mannopyranosyl-(1 $\rightarrow$ 2)- $\alpha$-D-mannopyranosyl- $(1 \rightarrow 3)-[\alpha-D-$ mannopyranosyl-(1 $\rightarrow 2)-\alpha-D$-mannopyranosyl- $(1 \rightarrow 4)-\alpha-D-$ mannopyranosyl-(1 $\rightarrow$ 6)- $\beta$-D-mannopyranoside (12). Compound 12 was synthesized according to general procedure A using following amounts: 11 (6.0 mg; $0.005 \mathrm{mmol})$ in $\mathrm{MeOH} /$ water $(2: 1 ; 1 \mathrm{~mL}), \mathrm{K}_{2} \mathrm{CO}_{3}(7.0 \mathrm{mg} ; 0.05 \mathrm{mmol})$, imidazole-1sulfonyl azide hydrochloride $(4.2 \mathrm{mg} ; 0.020 \mathrm{mmol})$ and a solution of $\mathrm{CuSO}_{4} \times 5 \mathrm{H}_{2} \mathrm{O}(0.1 \mathrm{M}$ in water; $5 \mu \mathrm{L} ; 4 \mu \mathrm{mol})$ which gave 12 as colorless solid (3.6 mg; 59\%); ${ }^{1} \mathrm{H}$ NMR (600 $\left.\mathrm{MHz}, \mathrm{D}_{2} \mathrm{O}\right): \delta=5.46\left(\mathrm{~d}, J=1.6 \mathrm{~Hz}, 1 \mathrm{H}, \mathrm{H}-1^{\mathrm{F}}\right), 5.31(\mathrm{~d}, J=1.4$ $\left.\mathrm{Hz}, 1 \mathrm{H}, \mathrm{H}-1^{\mathrm{B}}\right), 5.27\left(\mathrm{~d}, J=1.6 \mathrm{~Hz}, 1 \mathrm{H}, \mathrm{H}-1^{\mathrm{C}}\right), 5.01$ and 5.00 $\left(2 \mathrm{~d}, J=1.7 \mathrm{~Hz}, 2 \mathrm{H}, \mathrm{H}-1^{\mathrm{G}}, \mathrm{H}-1^{\mathrm{D}}\right), 4.87\left(\mathrm{~d}, J=1.2 \mathrm{~Hz}, 1 \mathrm{H}, \mathrm{H}-1^{\mathrm{E}}\right)$, $4.64\left(\right.$ br s, $\left.1 \mathrm{H}, \mathrm{H}-1^{\mathrm{A}}\right), 4.10$ (br. d, $J=3.2 \mathrm{~Hz}, 1 \mathrm{H}, \mathrm{H}-2^{\mathrm{A}}$ ), 4.07$4.02\left(\mathrm{~m}, 5 \mathrm{H}, \mathrm{H}-2^{\mathrm{C}}, \mathrm{H}-2^{\mathrm{B}}, \mathrm{H}-2^{\mathrm{F}}, \mathrm{H}-2^{\mathrm{D}}, \mathrm{H}-2^{\mathrm{G}}\right), 3.98-3.59(\mathrm{~m}, 38$ $\mathrm{H}), 3.50$ (ddd, $\left.J=1.9,5.8,9.7 \mathrm{~Hz}, 1 \mathrm{H}, \mathrm{H}-5^{\mathrm{A}}\right), 3.43-3.39(\mathrm{~m}, 2$ $\mathrm{H}, \mathrm{CH}_{2} \mathrm{CH}_{2} \mathrm{~N}_{3}$ ), 1.89-1.84 (m, $\left.2 \mathrm{H}, \mathrm{CH}_{2} \mathrm{CH}_{2} \mathrm{~N}_{3}\right) ;{ }^{13} \mathrm{C} \mathrm{NMR}$ (150 MHz, $\mathrm{D}_{2} \mathrm{O}$, selected data from HSQC-experiments): $\delta=$ $102.9\left(2 \mathrm{C}, \mathrm{C}-1^{\mathrm{D}}, \mathrm{C}-1^{\mathrm{G}}\right), 101.4\left(\mathrm{C}-1^{\mathrm{B}}\right), 101.3\left(\mathrm{C}-1^{\mathrm{C}}\right), 100.7(\mathrm{C}-$ $\left.1^{\mathrm{F}}\right), 100.6\left(\mathrm{C}-1^{\mathrm{A}}\right), 100.0\left(\mathrm{C}-1^{\mathrm{E}}\right), 81.5\left(\mathrm{C}-3^{\mathrm{A}}\right), 74.8\left(\mathrm{C}-5^{\mathrm{A}}\right), 48.7$ $\left(\mathrm{CH}_{2} \mathrm{CH}_{2} \mathrm{~N}_{3}\right), 28.9\left(\mathrm{CH}_{2} \mathrm{CH}_{2} \mathrm{~N}_{3}\right)$; ESI-TOF HRMS: $m / z$ calcd for $\mathrm{C}_{45} \mathrm{H}_{77} \mathrm{~N}_{3} \mathrm{O}_{36}\left[\mathrm{M}+\mathrm{H}^{+}\right]^{+}$: 1236.4360 ; found: 1236.4353 .

Synthesis of BSA conjugates $13,14,15 a, 15 b$, and $16 a-c$ has been reported. $^{25}$

Synthesis of BSA Conjugate 15c. The preparation was carried out according to general method B using $5(6.0 \mathrm{mg} ; 5$ $\mu$ mol; 333 equiv), $2 \mathrm{~mL}$ aqu. $\mathrm{NaHCO}_{3}$ and $2 \mathrm{~mL}$ thiophosgene solution $\left(12 \mu \mathrm{mol}\right.$ in $\left.\mathrm{CHCl}_{3}\right)$. After completion of isothiocyanate formation and removal of organic solvent, incubation with BSA (1 mg; $15 \mathrm{nmol})$ was performed in buffer A $(0.5 \mathrm{~mL})$. Processing as described afforded $5.0 \mathrm{mg}$ of $15 \mathrm{c}$. MALDI-TOF MS analysis revealed a ligand/BSA ratio of 6.4:1.

Synthesis of adipic amide conjugates $20 \boldsymbol{a}-\boldsymbol{d}$ and $\mathbf{2 1 a}-\mathbf{c}$. Compounds 20a-d were synthesized according to general procedure $\mathrm{C}$ using the following amounts: $5(0.2 \mathrm{mg}$; $0.17 \mu \mathrm{mol}$; 5 equiv) and $N, N^{\prime}$-adipoylbis (succinimide) $(0.6 \mathrm{mg} ; 1.65 \mu \mathrm{mol}$; 50 equiv) in DMSO $(0.2 \mathrm{~mL}), \mathrm{NEt}_{3}(0.16 \mu \mathrm{L} ; 1.1 \mu \mathrm{mol})$. BSA $(2.2 \mathrm{mg} ; 33 \mathrm{nmol})$ in $0.5 \mathrm{~mL}$ PBS-buffer. MALDI-TOF mass spectroscopic analysis of 20a revealed a ligand/BSA ratio of $1.1: 1$.

$5(0.6 \mathrm{mg} ; 0.50 \mu \mathrm{mol} ; 10$ equiv $)$ and $N, N^{\prime}$-adipoylbis(succinimide) ( $1.7 \mathrm{mg} ; 4.96 \mu \mathrm{mol} ; 100$ equiv) in DMSO (0.2 $\mathrm{mL}), \mathrm{NEt}_{3}(0.23 \mu \mathrm{L} ; 1.6 \mu \mathrm{mol})$. BSA $(3.3 \mathrm{mg} ; 50 \mathrm{nmol})$ in 0.5 $\mathrm{mL}$ PBS-buffer. MALDI-TOF mass spectroscopic analysis of $20 \mathrm{~b}$ revealed a ligand/BSA ratio of 3.9:1.

5 ( $1 \mathrm{mg} ; 0.83 \mu \mathrm{mol} ; 20$ equiv) and $N, N^{\prime}$-adipoylbis(succinimide) (2.8 mg; $8.26 \mu \mathrm{mol} ; 200$ equiv) in DMSO (0.3
$\mathrm{mL}), \mathrm{NEt}_{3}(0.38 \mu \mathrm{L} ; 2.7 \mu \mathrm{mol})$. BSA $(2.7 \mathrm{mg} ; 41 \mathrm{nmol})$ in 0.5 $\mathrm{mL}$ PBS-buffer. MALDI-TOF mass spectroscopic analysis of 20c revealed a ligand/BSA ratio of 4.8:1.

5 ( $1 \mathrm{mg} ; 0.83 \mu \mathrm{mol} ; 50$ equiv) and $N, N^{\prime}$-adipoylbis(succinimide) ( $2.8 \mathrm{mg} ; 8.26 \mu \mathrm{mol} ; 500$ equiv) in DMSO (0.3 $\mathrm{mL}), \mathrm{NEt}_{3}(0.38 \mu \mathrm{L} ; 2.7 \mu \mathrm{mol})$. BSA $(1.1 \mathrm{mg} ; 16 \mathrm{nmol})$ in 0.5 $\mathrm{mL}$ PBS-buffer. MALDI-TOF mass spectroscopic analysis of 20d revealed a ligand/BSA ratio of $8: 1$.

Compounds $21 \mathrm{a}-\mathrm{c}$ were synthesized according to general procedure $\mathrm{C}$ with a minor modification using the following amounts: 7 ( $1 \mathrm{mg} ; 0.83 \mu \mathrm{mol} ; 20$ equiv) and $N, N^{\prime}$-adipoylbis(succinimide) ( $2.8 \mathrm{mg} ; 8.26 \mu \mathrm{mol} ; 200$ equiv) in DMSO (0.3 $\mathrm{mL}), \mathrm{NEt}_{3}(0.38 \mu \mathrm{L} ; 2.7 \mu \mathrm{mol})$. For the work up $\mathrm{H}_{2} \mathrm{O}$ instead of PBS was added followed by washing with EtOAc. The intermediate was lyophilized and then conjugated to BSA (2.7 $\mathrm{mg} ; 41 \mathrm{nmol}$ ) in $0.5 \mathrm{~mL}$ PBS-buffer. MALDI-TOF mass spectroscopic analysis of 21a revealed a ligand/BSA ratio of 3.7:1.

7 (0.5 mg; $0.41 \mu \mathrm{mol} ; 20$ equiv) and $N, N^{\prime}$-adipoylbis(succinimide) ( $1.4 \mathrm{mg} ; 4.13 \mu \mathrm{mol} ; 200$ equiv) in DMSO (0.2 $\mathrm{mL}), \mathrm{NEt}_{3}(0.19 \mu \mathrm{L} ; 1.4 \mu \mathrm{mol})$. BSA $(1.4 \mathrm{mg} ; 21 \mathrm{nmol})$ in 0.5 $\mathrm{mL}$ PBS-buffer. MALDI-TOF mass spectroscopic analysis of $21 \mathbf{b}$ revealed a ligand/BSA ratio of $5: 1$.

7 ( $1 \mathrm{mg} ; 0.83 \mu \mathrm{mol} ; 40$ equiv) and $N, N^{\prime}$-adipoylbis(succinimide) ( $2.8 \mathrm{mg} ; 8.26 \mu \mathrm{mol} ; 400$ equiv) in DMSO (0.3 $\mathrm{mL}), \mathrm{NEt}_{3}(0.38 \mu \mathrm{L} ; 2.7 \mu \mathrm{mol})$. BSA $(1.4 \mathrm{mg} ; 21 \mathrm{nmol})$ in 0.5 $\mathrm{mL}$ PBS-buffer. MALDI-TOF mass spectroscopic analysis of $21 \mathrm{c}$ revealed a ligand/BSA ratio of 8.3:1.

$N$-\{[5-N-(tert-Butyloxycarbonylamino)-pentanoyl]-(5aminopentanoyl)\}tris [(propargyloxy)methyl]-aminomethane (24). Compound $22(0.3 \mathrm{~g} ; 0.68 \mathrm{mmol})$ was dissolved in dry DCM $(5 \mathrm{~mL})$ under argon and was cooled to $0{ }^{\circ} \mathrm{C}$. Then TFA $(0.53 \mathrm{~mL} ; 6.9 \mathrm{mmol})$ was added and the solution was stirred at room temperature for $3 \mathrm{~h}$. The solvent was then removed and the residue 23 was coevaporated with $\mathrm{CHCl}_{3}$ three times.

Next, the free amine 23 was dissolved in dry DMF $(1 \mathrm{~mL})$ under Argon followed by the addition of Boc-5-aminopentanoic acid $(0.165 \mathrm{~g} ; 0.76 \mathrm{mmol}), \mathrm{N}$-methylmorpholine $(0.167 \mathrm{~mL}$; $1.52 \mathrm{mmol})$ and HATU $(0.289 \mathrm{~g} ; 0.76 \mathrm{mmol})$. The mixture was stirred at $\mathrm{rt}$ for $16 \mathrm{~h}$. The reaction was quenched by the addition of aq satd $\mathrm{NH}_{4} \mathrm{Cl}$. DCM was added, phases were separated and the organic phase was washed with water and dried over $\mathrm{Na}_{2} \mathrm{SO}_{4}$. Concentration of the organic phase gave a crude product which was purified by column chromatography (DCM $\rightarrow 20: 1 \mathrm{DCM}-\mathrm{MeOH})$ to give 24 as a yellow oil $(0.247 \mathrm{~g} ; 67 \%)$; ${ }^{1} \mathrm{H} \mathrm{NMR}\left(600 \mathrm{MHz}^{\mathrm{CDCl}} \mathrm{CD}_{3}\right): 6.15$ (bs, $\left.1 \mathrm{H}, \mathrm{NH}\right), 5.78[\mathrm{~s}, 1 \mathrm{H}$, $\mathrm{C}\left(\mathrm{CH}_{2} \mathrm{OR}\right)_{3}-\mathrm{NH}$ ], 4.80 (bs, $\left.1 \mathrm{H}, \mathrm{NH}-\mathrm{Boc}\right), 4.09[\mathrm{~d}, \mathrm{~J}=2.4 \mathrm{~Hz}$, $\left.6 \mathrm{H}, \mathrm{C}\left(\mathrm{CH}_{2} \mathrm{OCH}_{2} \mathrm{CCH}\right)_{3}\right], 3.78\left[\mathrm{~s}, 6 \mathrm{H}, \mathrm{C}\left(\mathrm{CH}_{2} \mathrm{OCH}_{2} \mathrm{CCH}\right)_{3}\right]$, $3.18\left(\mathrm{dt}, J_{\mathrm{NH}, \mathrm{CH} 2}=J_{\mathrm{CH} 2, \mathrm{CH} 2}=6.3 \mathrm{~Hz}, 2 \mathrm{H}, \mathrm{H}-5^{\prime}\right), 3.07(\mathrm{~m}, 2 \mathrm{H}$, $\mathrm{H}-5), 2.42\left(\mathrm{t}, J=2.2 \mathrm{~Hz}, 3 \mathrm{H}, \mathrm{HCCCH}_{2}\right), 2.17-2.11(\mathrm{~m}, 4 \mathrm{H}, \mathrm{H}-$ 2, H-2'), 1.63-1.55 (m, 4 H, H-3, H-3'), 1.50-1.42 (m, 4 H, H4, $\left.\mathrm{H}-4^{\prime}\right), 1.38\left[\mathrm{bs}, 9 \mathrm{H},\left(\mathrm{CH}_{3}\right)_{3} \mathrm{C}\right] ;{ }^{13} \mathrm{C} \mathrm{NMR}(150 \mathrm{MHz}$, $\mathrm{CDCl}_{3}$ ): 173.2 (C-1'), 173.1 (C-1), 79.5 (3 C, $\left.\mathrm{CH}_{2} \mathrm{CCH}\right), 79.1$ $\left(\mathrm{CCH}_{3}\right), 74.7\left(3 \mathrm{C}, \mathrm{CH}_{2} \mathrm{CCH}\right), 68.5[3 \mathrm{C}, \mathrm{C}-$ $\left.\left(\mathrm{CH}_{2} \mathrm{OCH}_{2} \mathrm{CCH}\right)_{3}\right], 59.3\left[\mathrm{NHC}\left(\mathrm{CH}_{2} \mathrm{R}\right)_{3}\right], 58.7$ [3 C, C$\left.\left(\mathrm{CH}_{2} \mathrm{OCH}_{2} \mathrm{CCH}\right)_{3}\right], 38.9\left(2 \mathrm{C}, \mathrm{C}-5, \mathrm{C}-5^{\prime}\right), 36.4(\mathrm{C}-2), 35.9$ (C$\left.2^{\prime}\right), 29.5$ (2 C, C-4, C-4'), $28.6\left(3 \mathrm{C}, \mathrm{CH}_{3}\right), 22.8$ (C-3), 22.4 (C$\left.3^{\prime}\right)$; ESI-TOF HRMS: $m / z$ calcd for $\mathrm{C}_{29} \mathrm{H}_{44} \mathrm{~N}_{3} \mathrm{O}_{9}\left[\mathrm{M}+\mathrm{H}^{+}\right]^{+}$: 534.3174 ; found: 534.3202 .

Linker Derivative 25. Compound 25 was synthesized according to general procedure $\mathrm{D}$ slightly modified using following amounts: 2 (4.1 mg; $0.005 \mathrm{mmol} ; 3.6$ equiv) in $2 \mathrm{~mL}$ 
water-tertBuOH (1:1), $22\left(24 \mu \mathrm{L} ; 0.05 \mathrm{M}\right.$ in tertBuOH), $\mathrm{CuSO}_{4}$ $\times 5 \mathrm{H}_{2} \mathrm{O}(24 \mu \mathrm{L} ; 0.05 \mathrm{M}$ in water $)$, Na-ascorbate $(24 \mu \mathrm{L} ; 0.025$ $\mathrm{M}$ in water). Product 25 ( $1.8 \mathrm{mg} ; 46 \%)$ was obtained as colorless solid. ${ }^{1} \mathrm{H}$ NMR $\left(600 \mathrm{MHz}, \mathrm{D}_{2} \mathrm{O}\right): 7.92$ (s, H-triazole), anomeric protons: 5.29 (d, $J=1.0 \mathrm{~Hz}, 1 \mathrm{H}), 5.24(\mathrm{~d}, J=1.6 \mathrm{~Hz}, 1 \mathrm{H}), 4.98$ $(\mathrm{d}, J=1.3 \mathrm{~Hz}), 4.80(\mathrm{~d}, J=1.6 \mathrm{~Hz})$ and $4.52(\mathrm{bs}, 1 \mathrm{H})$, selected linker signals: $2.92\left(\mathrm{t}, J=6.6 \mathrm{~Hz}, 2 \mathrm{H}, \mathrm{CH}_{2} \mathrm{NH}\right), 1.45-1.38(\mathrm{~m}, 2$ $\left.\mathrm{H}, \mathrm{COCH}_{2} \mathrm{CH}_{2}\right), 1.33\left(\mathrm{~s}, 9 \mathrm{H},\left(\mathrm{CH}_{3}\right)_{3} \mathrm{C}\right)$.

Linker Derivative 26. Compound 26 was synthesized according to general procedure $\mathrm{E}$ using the following amounts: $25(2.0 \mathrm{mg})$ afforded 26 (1.7 mg; 88\%). ${ }^{1} \mathrm{H}$ NMR (600 MHz, $\mathrm{D}_{2} \mathrm{O}$ ): 7.93 (s, H-triazole), anomeric protons: 5.29 (d, $J=1.7$ $\mathrm{Hz}, 1 \mathrm{H}), 5.24(\mathrm{~d}, J=1.9 \mathrm{~Hz}, 1 \mathrm{H}), 4.98(\mathrm{~d}, J=1.9 \mathrm{~Hz}), 4.80(\mathrm{~d}, J$ $=1.4 \mathrm{~Hz}), 4.51(\mathrm{~d}, J=1.7 \mathrm{~Hz}, 1 \mathrm{H})$, selected linker signals: 2.91 $\left(\mathrm{t}, J=7.0 \mathrm{~Hz}, 2 \mathrm{H}, \mathrm{CH}_{2} \mathrm{NH}\right), 1.59-1.46\left(\mathrm{~m}, 4 \mathrm{H}, \mathrm{COCH}_{2} \mathrm{CH}_{2}\right.$, $\mathrm{CH}_{2} \mathrm{CH}_{2} \mathrm{NH}$ ). MALDI-TOF: $m / z$ calcd for $\mathrm{C}_{117} \mathrm{H}_{197} \mathrm{~N}_{11} \mathrm{O}_{82}$ : $\left[\mathrm{M}+\mathrm{H}^{+}\right]^{+}$: 3069.1656; found: 3068.833 .

Linker Derivative 27. Compound 27 was synthesized according to general procedure $\mathrm{D}$ using following amounts: 2 ( $5 \mathrm{mg} ; 0.006 \mathrm{mmol} ; 3.6$ equiv) in $0.5 \mathrm{~mL}$ water-tert $\mathrm{BuOH}(1: 1)$, $24(30 \mu \mathrm{L} ; 0.05 \mathrm{M}$ in tertBuOH$), \mathrm{CuSO}_{4} \times 5 \mathrm{H}_{2} \mathrm{O}(30 \mu \mathrm{L} ; 0.05$ $\mathrm{M}$ in water), Na-ascorbate ( $60 \mu \mathrm{L} ; 0.05 \mathrm{M}$ in degassed water). Product 27 (1.9 mg; 38\%) was obtained as colorless solid followed by recovered 2 (1.9 mg; 38\%). ${ }^{1} \mathrm{H}$ NMR (600 MHz, $\mathrm{D}_{2} \mathrm{O}$ ): 7.92 (s, H-triazole), anomeric protons: 5.28 (d, $J=1.5$ $\mathrm{Hz}, 1 \mathrm{H}), 5.24(\mathrm{~d}, J=1.9 \mathrm{~Hz}, 1 \mathrm{H}), 4.98(\mathrm{~d}, J=2.0 \mathrm{~Hz}), 4.79(\mathrm{~d}, J$ $=1.7 \mathrm{~Hz})$ and $4.52(\mathrm{bs}, 1 \mathrm{H})$; selected linker signals: $2.96(\mathrm{t}, J=$ $7.1 \mathrm{~Hz}, 2 \mathrm{H}, \mathrm{CH}_{2} \mathrm{NH}$ ), $2.10\left(\mathrm{t}, J=8.7 \mathrm{~Hz}, 2 \mathrm{H}, \mathrm{NCOCH}_{2}\right), 1.33$ (s, $\left.9 \mathrm{H},\left(\mathrm{CH}_{3}\right)_{3} \mathrm{C}\right)$.

MALDI-TOF: $m / z$ calcd for $\mathrm{C}_{127} \mathrm{H}_{214} \mathrm{~N}_{12} \mathrm{O}_{85}\left[\mathrm{M}+\mathrm{Na}^{+}\right]^{+}$: 3290.27; found: 3290.95 .

Linker Derivative 28. Compound 28 was synthesized according to general procedure $\mathrm{D}$ using the following amounts: 4 (7.2 mg; $0.008 \mathrm{mmol} ; 3.3$ equiv) in $1: 1$ water-tert $\mathrm{BuOH}(0.6$ $\mathrm{mL}), 24(48 \mu \mathrm{L} ; 0.05 \mathrm{M}$ in tertBuOH$), \mathrm{CuSO}_{4} \times 5 \mathrm{H}_{2} \mathrm{O}(48 \mu \mathrm{L}$; $0.05 \mathrm{M}$ in water), Na-ascorbate $(96 \mu \mathrm{L} ; 0.05 \mathrm{M}$ in degassed water). Product 28 (2.5 mg; 35\%) was obtained as colorless solid followed by recovered 4 (2.7 mg; 38\%). ${ }^{1} \mathrm{H}$ NMR (600 $\mathrm{MHz}, \mathrm{D}_{2} \mathrm{O}$ ): 7.97 (s, H-triazole), anomeric protons: 5.33 (d, $J=$ $1.3 \mathrm{~Hz}, 1 \mathrm{H}), 5.29$ (d, J = 1.7 Hz, $1 \mathrm{H}), 5.03(\mathrm{~d}, J=1.6 \mathrm{~Hz}), 4.89$ $(\mathrm{d}, J=1.6 \mathrm{~Hz}), 4.60(\mathrm{bs}, 1 \mathrm{H})$; selected linker signals: $3.02(\mathrm{t}, J=$ $\left.6.8 \mathrm{~Hz}, 2 \mathrm{H}, \mathrm{CH}_{2} \mathrm{NH}\right), 1.59-1.39\left(\mathrm{~m}, 6 \mathrm{H}, \mathrm{OCH}_{2} \mathrm{CH}_{2}\right.$, $\left.\mathrm{COCH}_{2} \mathrm{CH}_{2}, \mathrm{CH}_{2} \mathrm{CH}_{2} \mathrm{NH}\right), 1.38$ (s, $\left.9 \mathrm{H},\left(\mathrm{CH}_{3}\right)_{3} \mathrm{C}\right)$.

MALDI-TOF: $m / z$ calcd for $\mathrm{C}_{127} \mathrm{H}_{214} \mathrm{~N}_{12} \mathrm{O}_{85}\left[\mathrm{M}+\mathrm{K}^{+}\right]^{+}$: 3306.24; found: 3306.02 .

Linker Derivative 29. Compound 29 was synthesized according to general procedure $\mathrm{E}$ using the following amounts: 27 (3.5 mg) afforded 29 (3.4 mg; 100\%). ${ }^{1} \mathrm{H}$ NMR (600 MHz, $\mathrm{D}_{2} \mathrm{O}$ ): 7.97 (s, H-triazole), anomeric protons: 5.34 (d, $J=0.9$ $\mathrm{Hz}, 1 \mathrm{H}), 5.29(\mathrm{~d}, J=0.9 \mathrm{~Hz}, 1 \mathrm{H}), 5.03(\mathrm{~d}, J=1.3 \mathrm{~Hz}), 4.84(\mathrm{~d}, J$ $=1.9 \mathrm{~Hz}), 4.57(\mathrm{bs}, 1 \mathrm{H})$, selected linker signals: $2.99(\mathrm{t}, J=6.0$ $\left.\mathrm{Hz}, 2 \mathrm{H}, \mathrm{CH}_{2} \mathrm{NH}\right), 1.67-1.61\left(\mathrm{~m}, 2 \mathrm{H}, \mathrm{OCH}_{2} \mathrm{CH}_{2}\right), 1.53-1.37$ (m, $4 \mathrm{H}, \mathrm{COCH}_{2} \mathrm{CH}_{2}, \mathrm{CH}_{2} \mathrm{CH}_{2} \mathrm{NH}$ ).MALDI-TOF: $\mathrm{m} / z$ calcd for $\mathrm{C}_{122} \mathrm{H}_{206} \mathrm{~N}_{12} \mathrm{O}_{83}[\mathrm{M}+\mathrm{Na}]^{+}$: 3190.22; found: 3190.10 .

Linker Derivative 30. Compound $\mathbf{3 0}$ was synthesized according to general procedure E using following amounts: 28 (2 mg) afforded 30 (1.9 mg; 100\%); ${ }^{1} \mathrm{H}$ NMR (600 MHz $\left.\mathrm{D}_{2} \mathrm{O}\right): 7.97$ (s, H-triazole), anomeric protons: $5.33(\mathrm{~s}, 1 \mathrm{H})$, $5.29(\mathrm{~s}, 1 \mathrm{H}), 5.04(\mathrm{~d}, J=1.2 \mathrm{~Hz}), 4.89(\mathrm{~d}, J=1.4 \mathrm{~Hz}), 4.60(\mathrm{bs}, 1$ $\mathrm{H})$; selected linker signals: $2.99\left(\mathrm{t}, J=7.1 \mathrm{~Hz}, 2 \mathrm{H}, \mathrm{CH}_{2} \mathrm{NH}\right)$, 1.66-1.61 (m, $\left.2 \mathrm{H}, \mathrm{OCH}_{2} \mathrm{CH}_{2}\right), 1.50-1.38(\mathrm{~m}, 4 \mathrm{H}$, $\mathrm{COCH}_{2} \mathrm{CH}_{2}, \mathrm{CH}_{2} \mathrm{CH}_{2} \mathrm{NH}$ ). MALDI-TOF: $m / z$ calcd for $\mathrm{C}_{122} \mathrm{H}_{206} \mathrm{~N}_{12} \mathrm{O}_{83}[\mathrm{M}+\mathrm{H}]^{+}$: 3168.23; found: 3168.17 .
BSA Conjugate $31.29(1.7 \mathrm{mg} ; 0.5 \mu \mathrm{mol})$ was dissolved in a mixture of EtOH-water $(2: 1 ; 0.75 \mathrm{~mL})$ followed by the addition of diethylsquarate $(0.016 \mathrm{M}$ in $\mathrm{EtOH}, 10 \mu \mathrm{L})$. Then aq. $\mathrm{NaHCO}_{3}(0.1 \mathrm{M}, 0.2 \mathrm{~mL})$ was added and the mixture was stirred for $16 \mathrm{~h}$ at room temperature. The intermediate was purified on LH-20 gel (2:1 water-MeOH) and product containing fractions were lyophilized. The activated ligand was dissolved in $0.5 \mathrm{~mL}$ of $0.5 \mathrm{M}$ borate buffer $(\mathrm{pH}=9)$ followed by the addition of BSA $(1.8 \mathrm{mg} ; 27 \mathrm{nmol}$ ) and stirred for $66 \mathrm{~h}$ at room temperature. ${ }^{54}$ In order to get rid of remaining free ligand and salts the crude reaction mixture was centrifuged using a spin filter (Amicon $0.5 \mathrm{M}, 30 \mathrm{kDa}$ ) for $10 \mathrm{~min}$ (at $25^{\circ} \mathrm{C}$ and $14000 \times$ g). The remaining solution was washed twice with PBS buffer $\left(0.45 \mathrm{~mL}\right.$ each, $10 \mathrm{~min}$ at $25^{\circ} \mathrm{C}$ and $\left.14000 \times \mathrm{g}\right)$ and was then removed from the filter by centrifugation. MALDI-TOF mass spectroscopy of 31 revealed an average ligand/BSA ratio of 0.53:1.

BSA Conjugate 32. Compound 32 was synthesized according to general procedure $\mathrm{F}$ using the following amounts: $29(1.7 \mathrm{mg}$; $0.5 \mu \mathrm{mol})$ in $0.1 \mathrm{M} \mathrm{NaHCO}_{3}(1 \mathrm{~mL})$, thiophosgene $(1 \mathrm{~mL}$, $0.006 \mathrm{M}$ in $\left.\mathrm{CHCl}_{3}\right)$, BSA (1.7 mg; $\left.26 \mathrm{nmol}\right)$ in PBS buffer $(0.5$ $\mathrm{mL})$. Product 32 was obtained as white solid $(1.8 \mathrm{mg})$. MALDITOF mass spectroscopic analysis revealed a ligand/BSA ratio of 0.76:1.

BSA Conjugate 33. Compound 33 was synthesized according to general procedure $\mathrm{F}$ using the following amounts: 30 (1 mg; $0.3 \mu \mathrm{mol})$ in $0.1 \mathrm{M} \mathrm{NaHCO}_{3}(1 \mathrm{~mL})$, thiophosgene $(1 \mathrm{~mL}$, $0.006 \mathrm{M}$ in $\left.\mathrm{CHCl}_{3}\right)$, BSA ( $\left.1 \mathrm{mg} ; 14 \mathrm{nmol}\right)$ in buffer $(0.5 \mathrm{~mL})$. Product 33 was obtained as white solid in quantitative yield (1.1 $\mathrm{mg}$ ). MALDI-TOF mass spectroscopic analysis revealed a ligand/BSA ratio of $0.46: 1$.

BSA Conjugate 34. Conjugate 34 was synthesized according to general procedure $\mathrm{C}$ using $29(1 \mathrm{mg} ; 0.32 \mu \mathrm{mol}), N, N^{\prime}$ adipoylbis(succinimide) $(1.1 \mathrm{mg} ; 3.2 \mu \mathrm{mol})$ and $\mathrm{NEt}_{3}(0.01 \mu \mathrm{L}$; $0.69 \mathrm{mmol})$ in DMSO $(0.2 \mathrm{~mL})$, as well as $0.5 \mathrm{mg}$ BSA in PBSbuffer $(0.3 \mathrm{~mL})$. MALDI-TOF mass spectrometry analysis of 34 revealed a ligand/BSA ratio of $3: 1$.

BSA Conjugate 35. Conjugate 35 was synthesized according to general procedure C using $30(0.9 \mathrm{mg} ; 0.28 \mu \mathrm{mol}), N, N^{\prime}$ adipoylbis(succinimide) $(1.0 \mathrm{mg} ; 2.8 \mu \mathrm{mol})$ and $\mathrm{NEt}_{3}(0.01 \mu \mathrm{L}$; $0.94 \mathrm{mmol})$ in DMSO $(0.2 \mathrm{~mL})$, as well as $0.9 \mathrm{mg}$ BSA in PBSbuffer $(0.3 \mathrm{~mL})$. MALDI-TOF mass spectrometry analysis of 35 revealed a ligand/BSA ratio of 1.3:1.

\section{ASSOCIATED CONTENT}

\section{Supporting Information}

The Supporting Information is available free of charge on the ACS Publications website at DOI: 10.1021/acs.bioconjchem.8b00731.

NMR spectra of ligands, MALDI-TOF spectra of conjugates, BLI sensorgrams and oligonucleotide primers (PDF)

\section{AUTHOR INFORMATION}

\section{Corresponding Author}

*E-mail: paul.kosma@boku.ac.at.

ORCID

Paul Kosma: 0000-0001-5342-7161

\section{Notes}

The authors declare no competing financial interest. 


\section{ACKNOWLEDGMENTS}

Financial support of this work by the Austrian Science Fund FWF (grant P26919-N28 to PK), the Canadian Institutes of Health Research (grant IBC-150408 to RP), and the National Institutes of Health (grant R01 AI134299 to RP) is gratefully acknowledged. Personal support by the Michael Smith Foundation for Health Research (Scholar Award to RP) is also acknowledged. We furthermore thank Jean-François Bruxelle for critical review of this manuscript.

\section{REFERENCES}

(1) Doores, K. J. (2015) The HIV glycan shield as a target for neutralizing antibodies. FEBS J. 282, 4679-4691.

(2) Horiya, S., MacPherson, I. S., and Krauss, I. J. (2014) Recent strategies targeting HIV glycans in vaccine design. Nat. Chem. Biol. 10, 990-999.

(3) Burton, D. R., and Hangartner, L. (2016) Broadly neutralizing antibodies to HIV and their role in vaccine design. Annu. Rev. Immunol. 34, 635-659.

(4) Behrens, A.-J., Vasiljevic, S., Pritchard, L. K., Harvey, D. J., Andev, R. S., Krumm, S. A., Struwe, W. B., Cupo, A., Kumar, A., Zitzmann, N., et al. (2016) Composition and antigenic effects of individual glycan sites of a trimeric HIV-1 envelope glyoprotein. Cell Rep. 14, 26952706.

(5) Doores, K., Bonomelli, C., Harvey, D. J., Vasiljevic, S., Dwek, R. A., Burton, D. R., Crispin, M., and Scanlan, C. N. (2010) Envelope glycans of immunodeficiency virions are almost entirely oligomannose antigens. Proc. Natl. Acad. Sci. U. S. A. 107, 13800-13805.

(6) Panico, M., Bouché, L., Binet, D., O’Connor, M.-J., Rahman, D., Pang, P.-C., Canis, K., North, S. J., Desrosiers, R. C., Chertova, E., et al. (2016) Mapping the complete glycoproteome of virion-derived HIV-1 gp120 provides insights into broadly neutralizing antibody binding. Sci. Rep. 6, 32956.

(7) Cao, L., Pauthner, M., Andrabi, R., Rantalainen, K., Berndsen, Z., Diedrich, J. K., Menis, S., Sok, D., Bastidas, R., Park, S.-K., et al. (2018) Differential processing of HIV envelope glycans on the virus and soluble recombinant trimer. Nat. Commun. 9, 3693.

(8) Fernández-Tejada, A., Haynes, B. F., and Danishefsky, S. J. (2015) Designing synthetic vaccines for HIV. Expert Rev. Vaccines 14, 815831.

(9) Horiya, S., MacPherson, I. S., and Krauss, I. J. (2014) Recent strategies targeting HIV glycans in vaccine design. Nat. Chem. Biol. 10, 990-999.

(10) Krauss, I. J., Joyce, J. G., Finnefrock, A. C., Song, H. C., Dudkin, V. Y., Geng, X., Warren, J. D., Chastain, M., Shiver, J. W., and Danishefsky, S. J. (2007) Fully synthetic carbohydrate HIV antigens designed on the logic of the 2G12 antibody. J. Am. Chem. Soc. 129, 11042-11044.

(11) Astronomo, R. D., Kaltgrad, E., Udit, A. K., Wang, S. K., Doores, K., Huang, C. Y., Pantophlet, R., Paulson, J. C., Wong, C. H., Finn, M. G., and Burton, D. R. (2010) Defining criteria for oligomannose immunogens for HIV using icosahedral virus capsid scaffolds. Chem. Biol. 17, 357-370.

(12) Wang, S.-K., Liang, P.-H., Astronomo, R. D., Hsu, T.-L., Hsieh, S.-L., Burton, D. R., and Wong, C.-H. (2008) Targeting the carbohydrates on HIV-1: interaction pf oligomannose dendrons with human monoclonal antibody 2 G12 and DC-SIGN. Proc. Natl. Acad. Sci. U. S. A. 105, 3690-3695.

(13) Ni, J., Song, H., Wang, Y., Stamatos, N. M., and Wang, L. X. (2006) Toward a carbohydrate-based HIV-1 vaccine: Synthesis and immunological studies of oligomannose-containing glycoconjugates. Bioconjugate Chem. 17, 493-500.

(14) Li, H., and Wang, L.-X. (2004) Design and synthesis of a template-assembled oligomannose cluster as an epitope mimic for human HIV-neutralizing antibody 2G12. Org. Biomol. Chem. 2, 483488 .
(15) Kabanova, A., Adamo, R., Proietti, D., Berti, F., Tontini, M., Rappuoli, R., and Costantino, P. (2010) Preparation, characterization and immunogenicity of HIV-1 related high-mannose oligosaccharidesCRM 197 glycoconjugates. Glycoconjugate J. 27, 501-513.

(16) Liu, C.-C., Zhai, C., Zheng, X.-J., and Ye, X.-S. (2016) Altering the specificity of the antibody response to HIV gp 120 with a glycoconjugate antigen. ACS Chem. Biol. 11, 1702-1709.

(17) Wang, J., Li, H., Zou, G., and Wang, L- X. (2007) Novel templateassembled oligosaccharide clusters as epitope mimics for HIVneutralizing antibody 2G12. Design, synthesis, and antibody binding study. Org. Biomol. Chem. 5, 1529-1540.

(18) Bailey, J. J., and Bundle, D. R. (2014) Synthesis of high-mannose 1-thio glycans and their conjugation to protein. Org. Biomol. Chem. 12, 2193-2213.

(19) Horiya, S., Bailey, J. K., Temme, J. S., Schlippe, Y. V. G., and Krauss, I. J. (2014) Directed evolution of multivalent glycopeptides tightly recognized by HIV antibody 2 G12. J. Am. Chem. Soc. 136, 54075415.

(20) Joyce, J. G., Krauss, I. J., Song, H. C., Opalka, D. W., Grimm, K. M., Nahas, D. D., Esser, M. T., Hrin, R., Feng, M., Dudkin, V. Y., Chastain, M., Shiver, J. W., and Danishefsky, S. J. (2008) An oligosaccharide-based HIV-1 2G12 mimotope vaccine induces carbohydrate-specific antibodies that fail to neutralize HIV-1 virions. Proc. Natl. Acad. Sci. U. S. A. 105, 15684-15689.

(21) Astronomo, R. D., Lee, H.-K., Scanlan, C. N., Pantophlet, R., Huang, C.-Y., Wilson, I. A., Blixt, O., Dwek, R. A., Wong, C.-H., and Burton, D. R. (2008) A glycoconjugate antigen based on the recognition motif of a broadly neutralizing human immunodeficiency virus antibody, 2G12, is immunogenic but elicits antibodies unable to bind to self glycans of gp120. J. Virol. 82, 6359-6368.

(22) Kong, L., Julien, J.-P., Calarese, D., Scanlan, C., Lee, H.-K., Rudd, P., Wong, C.-H., Dwek, R. A., Burton, D. A., and Wilson, I. A. (2012). In Glycobiology and Drug Design, pp 187-215, American Chemical Society, Washington, DC.

(23) Clark, B. E., Auyeung, K., Fregolino, E., Parrilli, M., Lanzetta, R., De Castro, C., and Pantophlet, R. (2012) A bacterial lipooligosaccharide that naturally mimics the epitope of the HIV-neutralizing antibody 2G12 as a template for vaccine design. Chem. Biol. 19, 254-263.

(24) Trkola, A., Purtscher, M., Muster, T., Ballaun, C., Buchacher, A., Sullivan, N., Srinivasan, K., Sodroski, J., Moore, J. P., and Katinger, H. (1996) Human monoclonal antibody 2G12 defines a distinctive neutralization epitope on the gp120 glycoprotein of human immunodeficiency virus type 1. J. Virol. 70, 1100-1108.

(25) Calarese, D. A., Scanlan, C. N., Zwick, M. B., Deechongkit, S., Mimura, Y., Kunert, R., Zhu, P., Wormald, M. R., Stanfield, R. L., Roux, K. H., et al. (2003) Antibody domain exchange is an immunological solution to carbohydrate cluster recognition. Science 300, 2065-2071.

(26) Calarese, D. A., Lee, H.-K., Huang, C.-Y., Best, M. D., Astronomo, R. D., Stanfield, R. L., Katinger, H., Burton, D. R., Wong, C.-H., and Wilson, I. A. (2005) Dissection of the carbohydrate specificity of the broadly neutralizing anti-HIV-1 antibody 2G12. Proc. Natl. Acad. Sci. U. S. A. 102, 13372-13377.

(27) Scanlan, C. N. R., Pantophlet, R., Wormald, M. R., Ollmann Saphire, E., Stanfield, R., Wilson, I. A., Katinger, H., Dwek, R. A., Rudd, P. M., and Burton, D. R. (2002) The broadly neutralizing anti-human immunodeficiency virus tpye 1 antibody $2 \mathrm{G} 12$ recognizes a cluster of $\alpha 1 \rightarrow 2$ mannose residues on the outer face of gp120. J. Virol. 76, 73067321.

(28) Stanfield, R. L., De Castro, C., Marzaioli, A. M., Wilson, I. A., and Pantophlet, R. (2015) Crystal structure of the HIV neutralizing antibody $2 \mathrm{G} 12$ in complex with a bacterial oligosaccharide analog of mammalian oligomannose. Glycobiology 25, 412-419.

(29) Trattnig, N., Farcet, J.-B., Gritsch, P., Christler, A., Pantophlet, R., and Kosma, P. (2017) Synthesis of a pentasaccharide fragment related to the inner core region of rhizobial and agrobacterial lipopolysaccharides. J. Org. Chem. 82, 12346-12358.

(30) Pantophlet, R., Trattnig, N., Murrell, S., Lu, N., Chau, D., Rempel, C., Wilson, I. A., and Kosma, P. (2017) Bacterially derived 
synthetic mimetics of mammalian oligomannose prime antibody responses that neutralize HIV infectivity. Nat. Commun. 8, 1601.

(31) Pejchal, R., Doores, K. J., Walker, L. M., Khayat, R., Huang, P.-S., Wang, S.-K., Stanfield, R. L., Julien, J.-P., Ramos, A., Crispin, M., et al. (2011) A potent and broadly neutralizing antibody recognizes and penetrates the HIV glycan shield. Science 334, 1097-1103.

(32) Goddard-Borger, E. D., and Stick, R. V. (2007) An efficient, inexpensive, and shelf-stable diazotransfer reagent: imidazole-1sulfonyl azide hydrochloride. Org. Lett. 9, 3797-3800.

(33) Rostovtsev, V. V., Green, L. G., Fokin, V. V., and Sharpless, K. B. (2002) A stepwise Huisgen cycloaddition process: Copper(I)catalyzed regioselective "ligation" of azides and terminal alkynes. Angew. Chem., Int. Ed. 41, 2596-2599.

(34) Tornøe, C. W., Christensen, C., and Meldal, M. (2002) Peptidotriazoles on solid phase: [1,2,3]-triazoles by regiospecific copper(I)-catalyzed 1,3-dipolar cycloadditions of terminal alkynes to azides. J. Org. Chem. 67, 3057-3064.

(35) Nakamura, T., Kawai, Y., Kitamoto, N., Osawa, T., and Kato, Y. (2009) Covalent modification of lysine residues by allyl isothiocyanate in physiological conditions: plausible transformation of isothiocyanate from thiol to amine. Chem. Res. Toxicol. 22, 536-542.

(36) Mishra, N. K., Deepak Krishna, R. N. V., Sankararamakrishnan, R., and Verma, S. (2015) Controlling in vitro insulin amyloidosis with stable peptide conjugates: A combined experimental and computational study. J. Phys. Chem. B 119, 15395-15406.

(37) Jahouh, F., Saksena, R., Aiello, D., Napoli, A., Sindona, G., Kováč, P., and Banoub, J. H. (2010) Glycation sites in neoglycoconjugates from the terminal monosaccharide antigen of the O-PS of Vibrio cholerae O1, serotype Ogawa, and BSA revealed by matrix-assisted laser desorption-ionization tandem mass spectrometry. J. Mass Spectrom. 45, $1148-1159$.

(38) Huang, B. X., and Kim, H.-Y. (2004) Probing three-dimensional structure of bovine serum albumin by chemical cross-linking and mass spectrometry. J. Am. Soc. Mass Spectrom. 15, 1237-1247.

(39) Dotsey, E. Y., Gorlani, A., Ingale, S., Achenbach, C. J., Forthal, D. N., Feigner, P. L., and Gach, J. S. (2015) A high throughput protein microarray approach to classify HIV monoclonal antibodies and variants. PLoS One 10 (5), e0125581.

(40) Doores, K. J., Fulton, Z., Huber, M., Wilson, I. A., and Burton, D. R. (2010) Antibody $2 \mathrm{G} 12$ recognizes di-mannose equivalently in domain- and nondomain-exchanged forms but only binds the HIV-1 glycan shield if domain exchanged. J. Virol. 84, 10690-10699.

(41) Mobley, D. L., and Dill, K. A. (2009) Binding of small-molecule ligands to proteins: "what you see" is not always "what you get". Structure 17, 489-498.

(42) Chang, C. A., Chen, W., and Gilson, M. K. (2007) Ligand configurational entropy and protein binding. Proc. Natl. Acad. Sci. U.S. A. 104, 1534-1539.

(43) Diehl, C., Engström, O., Delaine, T., Håkansson, M., Genheden, S., Modig, K., Leffler, H., Ryde, U., Nilsson, U. J., and Akke, M. (2010) Protein flexibility and conformational entropy in ligand design targeting the carbohydrate recognition domain of galectin-3. J. Am. Chem. Soc. 132, 14577-14589.

(44) Chabre, Y. M., Contino-Pépin, C., Placide, V., Shiao, T. C., and Roy, R. (2008) Expeditive synthesis of glycodendrimer scaffolds based on versatile TRIS and mannoside derivatives. J. Org. Chem. 73, 56025605 .

(45) Marin, M. J., Rashid, A., Rejzek, M., Fairhurst, S. A., Wharton, S. A., Martin, S. R., McCauley, J. W., Wileman, T., Field, R. A., and Russell, D. A. (2013) Glyconanoparticles for the plasmonic detection and discrimination between human and avian influenza virus. Org. Biomol. Chem. 11, 7101-7107.

(46) Tiwari, V. K., Mishra, B. B., Mishra, K. B., Mishra, N., Singh, A. S., and Chen, X. (2016) Cu-catalyzed click reaction in carbohydrate chemistry. Chem. Rev. 116, 3086-3240.

(47) Tietze, L. F., Schroeter, C., Gabius, S., Brinck, U., GoerlachGraw, A., and Gabius, H. J. (1991) Bioconjugate Chem. 2, 148-153.
(48) Wurm, F. R., and Klok, H.-A. (2013) Be squared: expanding the horizon of squaric acid-mediated conjugations. Chem. Soc. Rev. 42, 8220-8236.

(49) Xu, P., Kelly, M., Vann, W. F., Qadri, F., Ryan, E. T., and Kovác, P. (2017) Conjugate vaccines from bacterial antigens by squaric acid chemistry: a closer look. ChemBioChem 18, 799-815.

(50) Loos, A., Van Droogenbroeck, B., Hillmer, S., Grass, J., Kunert, R., Cao, J., Robinson, D. G., Depicker, A., and Steinkellner, H. (2011) Production of monoclonal antibodies with a controlled N-glycosylation pattern in seeds of Arabidopsis thaliana. Plant Biotechnol. J. 9, 179-192.

(51) Loos, A., Gach, J. S., Hackl, T., Maresch, D., Henkel, T., Porodko, A., Bui-Minh, D., Sommeregger, W., Wozniak-Knopp, G., Forthal, D. N., et al. (2015) Glycan modulation and sulfoengineering of anti-HIV-1 monoclonal antibody PG9 in plants. Proc. Natl. Acad. Sci. U. S. A. 112, 12675-12680.

(52) Niemer, M., Mehofer, U., Torres Acosta, J. A., Verdianz, M., Henkel, T., Loos, A., Strasser, R., Maresch, D., Rademacher, T., Steinkellner, H., and Mach, L. (2014) The human anti-HIV antibodies 2F5, 2G12, and PG9 differ in their susceptibility to proteolytic degradation: down-regulation of endogenous serine and cysteine proteinase activities could improve antibody production in plant-based expression platforms. Biotechnol. J. 9, 493-500.

(53) Strasser, R., Stadlmann, J., Schahs, M., Stiegler, G., Quendler, H., Mach, L., Glossl, J., Weterings, K., Pabst, M., and Steinkellner, H. (2008) Generation of glyco-engineered Nicotiana benthamiana for the production of monoclonal antibodies with a homogeneous human-like N-glycan structure. Plant Biotechnol. J. 6, 392-402.

(54) Hou, S.-J., Saksena, R., and Kovac, P. (2008) Preparation of glycoconjugates by dialkyl squarate chemistry revisited. Carbohydr. Res. 343, 196-210. 